\title{
Differential Response of Floating and Submerged Leaves of Longleaf Pondweed to Silver lons
}

\author{
Nisha Shabnam ${ }^{1}$, P. Sharmila², Govindjee ${ }^{3}$, Hyunook Kim $^{1 *}$ and P. Pardha-Saradhi* \\ ${ }^{1}$ Department of Energy and Environmental System Engineering, University of Seoul, Seoul, South Korea, ${ }^{2}$ Department of \\ Chemistry, Indian Institute of Technology Delhi, New Delhi, India, ${ }^{3}$ Center for Biophysics and Quantitative Biology, University \\ of Illinois at Urbana-Champaign, Urbana, IL, United States, ${ }^{4}$ Department of Environmental Studies, University of Delhi, \\ New Delhi, India
}

\section{OPEN ACCESS}

Edited by: Raquel Esteban University of the Basque Country, Spain

Reviewed by: Carmen Arena,

University of Naples Federico II, Italy

Amy S. Verhoeven, University of St. Thomas,

United States

${ }^{*}$ Correspondence: Hyunook Kim h_kim@uos.ac.kr

P. Pardha-Saradhi ppsaradhi@gmail.com

Specialty section: This article was submitted to Functional Plant Ecology, a section of the journal Frontiers in Plant Science

Received: 04 January 2017 Accepted: 31 May 2017

Published: 21 June 2017

Citation:

Shabnam N, Sharmila P, Govindjee, Kim H and Pardha-Saradhi P (2017)

Differential Response of Floating and Submerged Leaves of Longleaf Pondweed to Silver lons. Front. Plant Sci. 8:1052. doi: 10.3389/fpls.2017.01052
In this study, we have investigated variations in the potential of floating and submerged leaves of longleaf pondweed (Potamogeton nodosus) to withstand silver ion $\left(\mathrm{Ag}^{+}\right.$)toxicity. Both floating and submerged leaves changed clear colorless $\mathrm{AgNO}_{3}$ solutions to colloidal brown in the presence of light. Transmission electron microscopy revealed the presence of distinct crystalline Ag-nanoparticles (Ag-NPs) in these brown solutions. Powder X-ray diffraction pattern showed that Ag-NPs were composed of $\mathrm{Ag}^{0}$ and $\mathrm{Ag}_{2} \mathrm{O}$. Photosystem (PS) II efficiency of leaves declined upon exposure to $\mathrm{Ag}^{+}$with a significantly higher decline in the submerged leaves than in the floating leaves. Similarly, $\mathrm{Ag}^{+}$treatment caused a significant reduction in the carboxylase activity of the ribulose bisphosphate carboxylase/oxygenase in leaves. The reduction in this carboxylase activity was significantly higher in the submerged than in the floating leaves. $\mathrm{Ag}^{+}$treatment also resulted in a significant decline in the levels of nonenzymatic and enzymatic antioxidants; the decline was significantly lower in the floating than in submerged leaves. X-ray photoelectron spectroscopy revealed the presence of $\mathrm{Ag}_{2} \mathrm{O}$ in these leaves. Inductively coupled plasma mass spectrometry analysis revealed a three-fold higher Ag content in the submerged than in floating leaves. Our study demonstrates that floating leaves of longleaf pondweed have a superior potential to counter $\mathrm{Ag}^{+}$-toxicity compared with submerged leaves, which could be due to superior potential of floating leaves to reduce $\mathrm{Ag}^{+}$to less/non-toxic $\mathrm{Ag}^{0} / \mathrm{Ag}_{2} \mathrm{O}$ nanoparticles/nanocomplexes. We suggest that modulating the genotype of longleaf pondweed to bear higher proportion of floating leaves would help in cleaning fresh water bodies contaminated with ionic forms of heavy metals.

Keywords: antioxidants, Ag-nanoparticles, ecophysiological adaptation, heterophyllous aquatic plant, photosystem II, Potamogeton nodosus

\footnotetext{
Abbreviations: Chl, chlorophyll; DHA, dehydroascorbate; DTNB, 5,5'-dithiobis-(2-nitrobenzoic acid); DTT, dithiothreitol; EDTA, ethylene diamine tetra acetic acid; EDX, energy dispersive X-ray; fcc, face cubic centered; $F_{0}$, minimum chlorophyll a fluorescence; $F_{\mathrm{m}}$, maximum chlorophyll $a$ fluorescence; $F_{\mathrm{v}}$, variable chlorophyll $a$ fluorescence $\left(F_{\mathrm{m}}-F_{\mathrm{o}}\right)$; GAE, gallic acid equivalent (s); GPX, guaiacol peroxidase; GR, glutathione reductase; GSH, reduced glutathione; MDA, malondialdehyde; MDHAR, monodehydroascorbate reductase; $\mathrm{NAD}(\mathrm{P})^{+}$, oxidized nicotinamide adenine dinucleotide (phosphate); $\mathrm{NAD}(\mathrm{P}) \mathrm{H}$, reduced nicotinamide adenine dinucleotide (phosphate); NEM, $\mathrm{N}$-ethylmaleimide; NP, nanoparticle; PS, photosystem; PVP, polyvinylpyrrolidone; PXRD, powder X-ray diffraction; ROS, reactive oxygen species; Rubisco, ribulose 1,5-biphosphate carboxylase/oxygenase; SAED, selected area electron diffraction pattern; SOD, superoxide dismutase; TCA, trichloroacetic acid; TEM, transmission electron microscope; Tris, tris-(hydroxymethyl)-aminomethane.
} 


\section{INTRODUCTION}

Human activities, in particular, industrialization and urbanization, have led to a drastic acceleration in heavy metal pollution of our surroundings and ecosystems (Nriagu, 1996). Negative impact of heavy metal(s) on the health of living beings (including the humans) and ecosystems is of serious concern; this effect is being increasingly felt over the past few decades. In view of its ecofriendly nature, bioremediation (i.e., use of living beings or their components for detoxification of pollutants through, e.g., transformation, and degradation) is being used as one of the key approaches to decrease the level of heavy metals in the surroundings (Dhir et al., 2009; Rai, 2009). Microbial-assisted removal of heavy metals has been a popular bioremediation process. However, due to difficulties in harnessing the microbes from soils or water, plant-based biosorption of heavy metals is now receiving greater attention across the world. A large number of plants are hyper-accumulators of heavy metals, so many researchers are now trying to understand hyper-accumulating strategies in these plants (Kamal et al., 2004; Dhir et al., 2009; Sharma and Dietz, 2009). Pardha-Saradhi et al. (2014a,b,c) have shown that terrestrial plants have the potential to biotransform precious heavy metal ions (e.g., $\mathrm{Au}^{3+}$ and $\mathrm{Ag}^{+}$) and essential metal ions (e.g., $\mathrm{Fe}^{3+}$ ) into less/non-toxic nanoparticles (NPs)/nanocomplexes. Shabnam et al. (2017) have recently demonstrated that Ag-NPs are significantly less toxic than ionic Ag.

Heavy metals released from industries and other sources often find their way into water bodies, e.g., lakes, rivers, and oceans (Rai, 2009). Phytoplanktons contribute to over 50\% of the organic material produced through photosynthetic $\mathrm{CO}_{2}$ fixation (Arrigo, 2005). However, research has, thus far, been focused mainly on the macrophytes simply because of the ease with which they can be handled and harvested. Amongst the macrophytes, attention has been given mostly to homophyllous aquatic plants. In spite of being better adapted to the fluctuating climatic conditions compared to homophyllous aquatic macrophytes, heterophyllous aquatic plants have received less attention from the researchers (Iida et al., 2009).

Pardha-Saradhi et al. (2014a) have used silver as an ideal model heavy metal, since response of plants to $\mathrm{Ag}^{+}$can be visually recorded and easily characterized. Anthropogenic activities such as mining, electroplating and photographic industry are responsible for the release of silver into our surroundings (Purcell and Peters, 1998; Ratte, 1999). No attempt has, thus far, been made to evaluate the impact of silver on any heterophyllous aquatic macrophyte. Longleaf pondweed has floating and submerged leaves. While floating leaves are present on the surface, submerged leaves are under water. Previously, we reported that the floating leaves have superior photosynthetic efficiency and antioxidant system compared to the submerged ones (Shabnam et al., 2015; Shabnam and Pardha-Saradhi, 2016). Therefore, in this study, we chose this plant to evaluate differences in the tolerance of these types of leaves to $\mathrm{Ag}^{+}$ toxicity. We have evaluated the impact of silver on photosynthesis and antioxidant system. Our findings revealed that these leaves possess potential to generate Ag-NPs on exposure to $\mathrm{Ag}^{+}$.
We believe that this potential of leaves to generate Ag-NPs is a mechanism to restrict the uptake of $\mathrm{Ag}^{+}$and thus, counter its toxic effects.

\section{MATERIALS AND METHODS}

\section{Experimental Procedure}

Longleaf pondweed (Potamogeton nodosus, Potamogetonaceae) was grown at the University of Delhi, as described by Shabnam et al. (2015). For studying the impact of $\mathrm{Ag}^{+}$on floating and submerged leaves of longleaf pondweed, fully expanded mature leaves were used. Leaves, after washing three times with doubledistilled water, were acclimatized under laboratory conditions for $3 \mathrm{~h}$. Silver nitrate $\left(\mathrm{AgNO}_{3}\right)$ was used to impose silver ion $\left(\mathrm{Ag}^{+}\right)$-toxicity. The leaves were exposed to different levels $(0,5$, $10,50,100,250$, and $500 \mu \mathrm{M}$ ) of $\mathrm{AgNO}_{3}$ in Borosil dishes (190 mm diameter $\times 100 \mathrm{~mm}$ height) under continuous white light $\left(120 \mu \mathrm{mol}\right.$ photons $\left.\mathrm{m}^{-2} \mathrm{~s}^{-1}\right)$ for $24 \mathrm{~h}$. Understandably, in this experimental setup floating leaves float and submerged leaves get submerged in test solution during experimental exposure.

Impact of $\mathrm{Ag}^{+}$on floating and submerged leaves of longleaf pondweed was evaluated by measuring (i) photosystem (PS) II efficiency; (ii) carboxylase activity of ribulose bisphosphate carboxylase/oxygenase (Rubisco); and (iii) enzymatic and nonenzymatic antioxidants according to the protocols of Shabnam and Pardha-Saradhi (2016).

\section{Analytical Methods Photosystem II Efficiency}

For determining PS II efficiency, leaves were dark-adapted for $40 \mathrm{~min}$ and $\mathrm{Chl} a$ fluorescence induction measurements were made on 8-10 different portions of leaves. Fluorescence transient, from $10 \mu$ s to $1 \mathrm{~s}$, was measured using a plant efficiency analyzer (PEA) (Handy PEA; Hansatech Ltd, Norfolk, United Kingdom); leaves were excited with red light (peak at $650 \mathrm{~nm}$ ) at an intensity of 3,500 $\mu \mathrm{mol}$ photons $\mathrm{m}^{-2} \mathrm{~s}^{-1}$, provided by an array of six lightemitting diodes (LEDs). At least five leaves were used for each treatment. Biolyzer software HP 3 (Bioenergetics Laboratory, University of Geneva, Geneva, Switzerland) was used to plot Chl $a$ fluorescence data. For details on measurement of Chl $a$ fluorescence, see Shabnam et al. (2015). Quantum efficiency of PS II activity was inferred from the ratio of variable $\left(F_{\mathrm{V}}\right)$ to maximum $\left(F_{\mathrm{m}}\right) \mathrm{Chl} a$ fluorescence, where $F_{\mathrm{v}}=F_{\mathrm{m}}-F_{\mathrm{o}}, F_{\mathrm{o}}$ being the minimum fluorescence (see Govindjee, 2004). Chl $a$ and $\mathrm{Chl} b$ levels of leaves were quantified according to the method and equations used by Arnon (1949).

\section{Carboxylase Activity of Rubisco}

Carboxylase activity of Rubisco (EC 4.1.1.39) was measured as described earlier (Shabnam and Pardha-Saradhi, 2016). Leaves were homogenized in chilled $50 \mathrm{mM}$ Tris- $\mathrm{HCl}$ buffer $(\mathrm{pH} 7.6)$ containing $1 \mathrm{mM}$ DTT, $5 \mathrm{mM}$ EDTA and 5\% PVP with acid washed sand in pre-chilled mortar and pestle. The homogenate was centrifuged at $15,000 \times g$ for $20 \mathrm{~min}$ at $4^{\circ} \mathrm{C}$, and the supernatant was used as a crude enzyme. The carboxylase 
activity of Rubisco was measured, at $25 \pm 2{ }^{\circ} \mathrm{C}$, using an assay mixture containing crude enzyme extract, Tris- $\mathrm{HCl}$ buffer (200 mM, pH 8.5), $1 \mathrm{mM}$ RuBP, $10 \mathrm{mM} \mathrm{NaHCO}_{3}, 5 \mathrm{mM}$ $\mathrm{MgCl}_{2}, 0.1 \mathrm{mM}$ DTT, $1 \mathrm{mM}$ ATP, 5 units of phosphoglycerate kinase, 5 units of glyceraldehyde-3-phosphate dehydrogenase, and $0.2 \mathrm{mM}$ NADH. Oxidation of NADH was recorded as decrease in absorbance at $340 \mathrm{~nm}$; the carboxylase activity of Rubisco was initially calculated in terms of nmoles of $\mathrm{NADH}$ oxidized $\min ^{-1} \mathrm{~g}^{-1}$ fresh weight. Subsequently carboxylase activity of Rubisco was extrapolated and expressed in terms of $\mathrm{CO}_{2}$ fixed $\min ^{-1} \mathrm{~g}^{-1}$ fresh weight.

\section{Determination of Silver in Leaves}

Silver content of leaves was measured using inductively coupled plasma mass spectrometry (ICP-MS) (NexION 300D, Perkin Elmer, Waltham, MA, United States) and expressed as mg silver $\mathrm{g}^{-1}$ dry weight. Leaves exposed to $\mathrm{Ag}^{+}$were also analyzed by X-ray photoelectron spectroscopy (XPS; Phi 5000 VersaProbe, Ulvac-Phi, Chigasaki, Japan).

\section{Determination of Non-enzymatic Antioxidants}

Levels of non-enzymatic antioxidants (i.e., phenolics, thiols, and ascorbate) were measured as described earlier (Shabnam and Pardha-Saradhi, 2016). Leaves were homogenized in chilled 5\% TCA with mortar and pestle. The homogenate was centrifuged at $20,000 \times g$ for $15 \mathrm{~min}$ at $4^{\circ} \mathrm{C}$, and the supernatant was used for determining the levels of total ascorbate, total phenolics and thiols, as described below.

\section{Total ascorbate}

The reaction mixture consisted of $200 \mu \mathrm{l}$ supernatant, $100 \mu \mathrm{l}$ DTT (10 mM), $100 \mu \mathrm{l}$ NEM (0.5\%), $500 \mu \mathrm{l}$ TCA (10\%), $400 \mu \mathrm{l}$ orthophosphoric acid (43\%), $400 \mu \mathrm{l} \alpha$ - $\alpha^{\prime}$-bipyridyl (4\%) and $200 \mu \mathrm{FeCl}_{3}$ (3\%); it was immediately vortexed to avoid the formation of any precipitate. This reaction mixture was incubated at $37^{\circ} \mathrm{C}$ for $1 \mathrm{~h}$ and the absorbance was measured at $525 \mathrm{~nm}$. The amount of total ascorbate was expressed as nmoles $\mathrm{g}^{-1}$ fresh weight.

\section{Total phenolics}

One $\mathrm{ml}$ of supernatant was incubated with a mixture of $1 \mathrm{ml}$ Folin-Ciocalteu reagent and $2 \mathrm{ml} \mathrm{Na}_{2} \mathrm{CO}_{3}(700 \mathrm{mM})$ for $1 \mathrm{~h}$ in dark at room temperature. Subsequently, absorbance of the reaction mixture was measured at $765 \mathrm{~nm}$. Total phenolic content was expressed as nmoles of GAE $\mathrm{g}^{-1}$ fresh weight, using a standard curve obtained with gallic acid.

\section{Thiols}

To $200 \mu \mathrm{l}$ supernatant, $775 \mu \mathrm{l} \mathrm{K} \mathrm{HPO}_{4}(500 \mathrm{mM})$ and $25 \mu \mathrm{l}$ 5,5'-Dithiobis (2-nitrobenzoic acid) (DTNB) (10 mM in $100 \mathrm{mM}$ phosphate buffer, $\mathrm{pH} 7.0$ ) were added. Absorbance of the samples was measured at $412 \mathrm{~nm}$ and corrected against the absorbance of a sample without added DTNB. Thiol content was expressed as nmoles $\mathrm{g}^{-1}$ fresh weight, using an extinction coefficient of $13.6 \mathrm{mM}^{-1} \mathrm{~cm}^{-1}$ at $412 \mathrm{~nm}$.

\section{Determination of Activities of Enzymatic Antioxidants}

The activities of antioxidant enzymes, such as SOD (EC 1.15.1.1), catalase (EC 1.11.1.6), GPX (EC 1.11.1.7), ascorbate peroxidase (APX, EC 1.11.1.11), MDHAR (EC 1.6.5.4), DHA reductase (DHAR, EC 1.8.5.1), and GR (EC 1.6.4.2) were measured as described earlier (Shabnam and PardhaSaradhi, 2016). Leaves were homogenized in chilled $50 \mathrm{mM}$ Tris-HCl buffer ( $\mathrm{pH}$ 7.6) containing $1 \mathrm{mM}$ DTT, $5 \mathrm{mM}$ EDTA and 5\% PVP with acid washed sand in chilled mortar and pestle. The homogenate was centrifuged at $15,000 \times g$ for $20 \mathrm{~min}$ at $4^{\circ} \mathrm{C}$. The supernatant was taken as a crude enzyme extract and was used for estimating activities of various antioxidant enzymes as briefly described below.

\section{Superoxide dismutase}

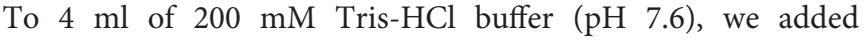
$200 \mu \mathrm{l}$ L-methionine $(20 \mathrm{mM}), 200 \mu \mathrm{l}$ EDTA $(0.1 \mathrm{mM})$, $100 \mu l$ hydroxylamine, $100 \mu l$ Triton X (0.1\%), $200 \mu l$ riboflavin $(0.5 \mathrm{mM})$ and the enzyme extract. Tubes containing the resultant reaction mixture were exposed to $120 \mu \mathrm{mol}$ photons $\mathrm{m}^{-2} \mathrm{~s}^{-1}$ of white light, using an incandescent lamp, at $25 \pm 2{ }^{\circ} \mathrm{C}$. After exposure to light for $45 \mathrm{~min}, 2 \mathrm{ml}$ of freshly prepared Greiss reagent [containing equal volumes of $0.1 \%$ naphthylethylenediamine dihydrochloride (NED) and $1 \%$ sulphanilamide dissolved in 5\% orthophosphoric acid] was added to the reaction mixture and absorbance was measured at $543 \mathrm{~nm}$. SOD activity was expressed in terms of nmoles of $\mathrm{O}_{2}{ }^{-}$consumed $\min ^{-1} \mathrm{~g}^{-1}$ fresh weight.

\section{Catalase}

Activity of catalase (CAT, EC 1.11.1.6) was determined by measuring the rate of oxygen evolution in a reaction mixture containing the enzyme extract in $200 \mathrm{mM}$ phosphate buffer ( $\mathrm{pH}$ 6.5) and $20 \mathrm{mM} \mathrm{H}_{2} \mathrm{O}_{2}$ at $25 \pm 2{ }^{\circ} \mathrm{C}$, using a Clark-type liquid phase $\mathrm{O}_{2}$ electrode (Hansatech, United Kingdom). The enzyme activity was expressed as nmoles of oxygen evolved $\min ^{-1} \mathrm{~g}^{-1}$ fresh weight.

\section{Guaiacol peroxidase}

The reaction mixture for determining activity of guaiacol peroxidase activity consisted of a reaction mixture consisting of $200 \mathrm{mM}$ phosphate buffer ( $\mathrm{pH} 6.5$ ), $2 \mathrm{mM}$ guaiacol and $20 \mathrm{mM}$ $\mathrm{H}_{2} \mathrm{O}_{2}$ incubated with enzyme extract, at $25 \pm 2{ }^{\circ} \mathrm{C}$. Enzyme activity was measured by recording increase in absorbance at $470 \mathrm{~nm}$ with time. The enzyme activity was expressed as nmoles of tetraguaiacol formed $\min ^{-1} \mathrm{~g}^{-1}$ fresh weight, using an extinction coefficient of $26.6 \mathrm{mM}^{-1} \mathrm{~cm}^{-1}$ at $470 \mathrm{~nm}$.

\section{Ascorbate peroxidase}

Ascorbate peroxidase (APX, EC 1.11.1.11) activity was determined by estimating the rate of oxidation of ascorbate at $290 \mathrm{~nm}$ in a reaction mixture consisting of $200 \mathrm{mM}$ Tris- $\mathrm{HCl}$ buffer ( $\mathrm{pH} 7.6$ ), $20 \mathrm{mM} \mathrm{H} \mathrm{O}_{2}, 1 \mathrm{mM}$ sodium azide, $2 \mathrm{mM}$ ascorbate and the enzyme extract, at $25 \pm 2{ }^{\circ} \mathrm{C}$. The activity of APX was expressed as nmoles of ascorbate oxidized $\mathrm{min}^{-1} \mathrm{~g}^{-1}$ fresh weight, using an extinction coefficient of $2.8 \mathrm{mM}^{-1} \mathrm{~cm}^{-1}$, at $290 \mathrm{~nm}$.

\section{Monodehydroascorbate reductase}

For measuring activity of MDHAR (EC 1.6.5.4), the reaction mixture consisted of $200 \mathrm{mM}$ Tris- $\mathrm{HCl}$ buffer 
( $\mathrm{pH}$ 7.6), the enzyme extract, $2 \mathrm{mM}$ ascorbate, 10 units of ascorbate oxidase and $0.2 \mathrm{mM}$ NADH. Decrease in absorbance at $340 \mathrm{~nm}$, due to the oxidation of $\mathrm{NADH}$, was measured at $25 \pm 2{ }^{\circ} \mathrm{C}$. Extinction coefficient of $6.2 \mathrm{mM}^{-1}$ $\mathrm{cm}^{-1}$ (at $340 \mathrm{~nm}$ ) was used to express the activity of MDHAR as nmoles of $\mathrm{NADH}$ oxidized $\min ^{-1} \mathrm{~g}^{-1}$ fresh weight.

\section{Dehydroascorbate reductase}

The reaction mixture for the determination of dehydroascorbate reductase (DHAR, EC 1.8.5.1) activity included $200 \mathrm{mM}$ Tris$\mathrm{HCl}$ buffer ( $\mathrm{pH}$ 7.6), enzyme extract, $1 \mathrm{mM}$ reduced glutathione (GSH), and $1 \mathrm{mM}$ dehydroascorbate. An increase in absorbance at $265 \mathrm{~nm}$, due to the formation of ascorbate, from DHA by DHAR, in the presence of GSH, was measured at $25 \pm 2{ }^{\circ} \mathrm{C}$. Enzyme activity was expressed in terms of nmoles of ascorbate formed $\min ^{-1} \mathrm{~g}^{-1}$ fresh weight, using an extinction coefficient of $14 \mathrm{mM}^{-1} \mathrm{~cm}^{-1}$ at $265 \mathrm{~nm}$.

\section{Glutathione reductase}

The reaction mixture for measuring GR (EC 1.6.4.2) activity consisted of $200 \mathrm{mM}$ Tris-HCl buffer ( $\mathrm{pH} 7.6$ ), enzyme extract, $1 \mathrm{mM}$ oxidized glutathione (GSSG) and $0.2 \mathrm{mM} \mathrm{NADH}$. Decrease in absorbance at $340 \mathrm{~nm}$, due to the oxidation of $\mathrm{NADH}$, was measured at $25 \pm 2{ }^{\circ} \mathrm{C}$. The activity of GR was expressed as nmoles of $\mathrm{NADH}$ oxidized $\min ^{-1} \mathrm{~g}^{-1}$ fresh weight, using extinction coefficient of $6.2 \mathrm{mM}^{-1} \mathrm{~cm}^{-1}$ (at $340 \mathrm{~nm}$ ).

\section{Characterization of Ag-NPs}

For TEM studies, $10 \mu \mathrm{l}$ of colloidal solution was drop-coated on a 200 mesh copper grid with an ultrathin continuous carbon film, and allowed to dry in a desiccator at room temperature. Grids were viewed under a TEM (Technai G2 T30, Lonate Pozzolo, Italy) at a voltage of $300 \mathrm{KV}$. The hardware associated with the instrument allowed us to obtain (i) the EDX analysis to measure the elemental composition of the particle sample; and (ii) the SAED analysis to determine the crystalline/amorphous nature of NPs.

For PXRD studies, colloidal solutions were centrifuged. The pellet obtained was re-suspended in distilled water, dropcoated on silica surface, dried in a desiccator, and then used for collecting PXRD pattern, using Rigaku Rotaflex RAD-B with copper target $\mathrm{CuK}(\alpha) 1$ radiation, with a tube voltage of $40 \mathrm{kV}$ and a current of $60 \mathrm{~mA}$ in 2 theta $(\theta)$ range of $30-80^{\circ}$.

\section{Statistical Analysis}

All the experiments were carried out independently six times. The data obtained were statistically tested with ANOVA using the general linear model. The variations between the means of treatments were compared using Duncan's multiple range test (at $P \leq 0.05$ ). All these statistical analyses were performed using IBM-SPSS statistical software, version 22.0 (IBM Corporation, Armonk, NY, United States).

\section{RESULTS}

\section{Potential of Floating and Submerged Leaves to Generate Ag-NPs}

We observed alteration of clear colorless $\mathrm{AgNO}_{3}$ solutions to colloidal brown when incubated with floating and submerged leaves of longleaf pondweed within $24 \mathrm{~h}$ (Figures 1A,B). Clear colorless $\mathrm{AgNO}_{3}$ solutions turned colloidal brown due to the formation of Ag-NPs (Shabnam et al., 2016). $\mathrm{AgNO}_{3}$ solutions incubated in the absence of leaves did not show any alteration in color, thus confirming that leaves were responsible for the observed color change. Floating leaves turned $\mathrm{AgNO}_{3}$ solutions colloidal brown more intensively compared to the submerged leaves, although only one side of floating leaves was in contact with test solution. Supplementary Figure 1 shows experimental setup revealing that the floating leaves possess superior potential to turn clear colorless $\mathrm{AgNO}_{3}(500 \mu \mathrm{M})$ solutions colloidal brown compared to submerged leaves. For depicting the gradation in color with better clarity the test solutions (i.e., different concentrations of $\mathrm{AgNO}_{3}$ ) incubated with floating and submerged leaves for $24 \mathrm{~h}$ were transferred to test tubes along with leaves (Figures 1A,B). However, absorption spectra of the brown colloidal solution did not show any Ag-NP specific absorption peak.

Transmission electron microscopy revealed the presence of distinct NPs of varying shapes and sizes $(\sim 10-80 \mathrm{~nm})$ in these colloidal brown solutions (Figures 1C-F). EDX of these NPs showed peaks specific to Ag (Figures 1I,J). SAED pattern revealed the crystalline nature of these Ag-NPs (Figures 1G,H). PXRD patterns showed Bragg reflections (111), (200), and (311), revealing crystalline nature and face centered cubic structure of $\mathrm{Ag}^{0}$-NPs (Figures 1K,L) (Pardha-Saradhi et al., 2014a). Additional peaks observed in the PXRD spectra might be due to Bragg reflections $(111)^{*},(211)^{*},(220)^{*},(221)^{*}$ of cubic $\mathrm{Ag}_{2} \mathrm{O}$ (Figures 1K,L).

\section{Impact of $\mathrm{Ag}^{+}$on Photosynthesis in Floating and Submerged Leaves}

In view of large differences in photosynthetic activities between floating and submerged leaves (Shabnam et al., 2015), we examined the effects of $\mathrm{Ag}^{+}$on Photosystem II (PS II) efficiency of these leaves. Photosystem II efficiency (maximum quantum yield) is often determined as a ratio of variable Chl $a$ fluorescence to maximum $\mathrm{Chl} a$, i.e., $F_{\mathrm{v}} / F_{\mathrm{m}}$. Chl $a$ fluorescence of oxygenic organisms shows a rise from a basal level $\left(F_{\mathrm{o}}\right)$ (i.e., minimum fluorescence) to the maximum $\left(F_{\mathrm{m}}\right)$ (Strasser et al., 1995; Stirbet and Govindjee, 2012; Shabnam et al., 2015, 2017). $F_{\mathrm{o}}$ and $F_{\mathrm{m}}$ values of both floating and submerged leaves declined significantly on exposure to $\mathrm{Ag}^{+}$; the decline was significantly higher in the submerged leaves than in the floating ones (Table 1). $\mathrm{Ag}^{+}$, like other heavy metal ions, brought about a significant decline in the quantum yield of PS II activity, as inferred from $F_{\mathrm{v}} / F_{\mathrm{m}}$ values, in both floating and submerged leaves (Figure 2). However, at any given concentration, the decline in $F_{\mathrm{v}} / F_{\mathrm{m}}$ was significantly higher in the submerged leaves. 

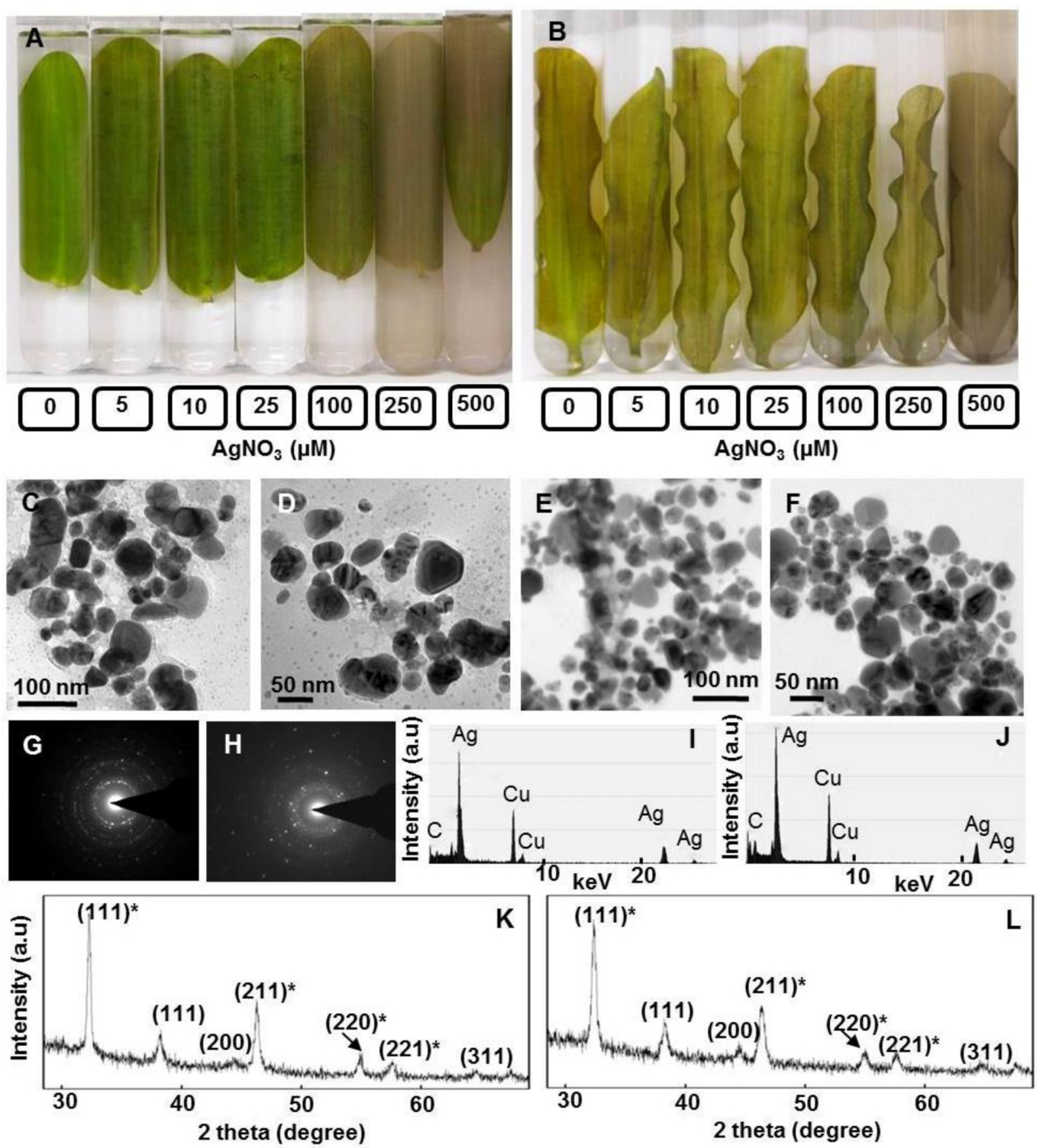

FIGURE 1 | Potential of floating and submerged leaves of longleaf pondweed (Potamogeton nodosus) to generate Ag-NPs. Photographs were taken after $24 \mathrm{~h}$ exposure of floating $(\mathbf{A})$ and submerged $(\mathbf{B})$ leaves to varying concentrations of $\mathrm{AgNO}_{3}$ (in $\mu \mathrm{M}$ ) in Borosil dishes (190 mm diameter $\times 100 \mathrm{~mm}$ height, in order to ensure that floating leaves remain floating and submerged leaves remain submerged in respective test solution during the course of exposure to AgNO$\left._{3}\right)$. TEM (C-F),

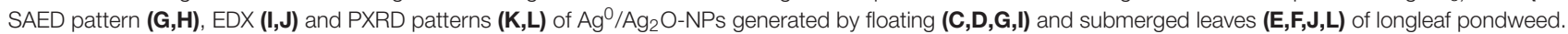
PXRD patterns $\mathbf{( K , L )}$ show Bragg reflections specific to crystalline face-centered cubic structure of $\mathrm{Ag}^{0}$ (in parenthesis without star) and cubic structure of $\mathrm{Ag}_{2} \mathrm{O}$ (in parenthesis with star).

Figure 3 shows the fast (up to a second) polyphasic Chl a fluorescence transients of floating and submerged leaves which were exposed to different $\mathrm{Ag}^{+}$levels. All oxygen-evolving organisms show polyphasic $\mathrm{Chl} a$ fluorescence transients (also called the OJIP curves) with distinct O, J, I, and P steps (Figure 3). In these curves, "O" is the minimum fluorescence $\left(F_{\mathrm{o}}\right)$, "P" is the peak $\left(F_{\mathrm{m}}\right)$, and " $\mathrm{J}$ " and "I" are intermediate levels. The polyphasic rise of Chl $a$ fluorescence transient was severely reduced in both floating and submerged leaves, exposed to $\mathrm{Ag}^{+}$(Figure 3), which is in agreement with the decline in $F_{\mathrm{v}} / F_{\mathrm{m}}$. The decline in the amplitude of fluorescence was significantly higher in submerged leaves than in floating leaves, revealing superior potential of the latter to tolerate $\mathrm{Ag}^{+}$than the former. Extreme sensitivity of submerged leaves to $\mathrm{Ag}^{+}$-toxicity was also evident from the loss in the polyphasic nature of $\mathrm{Chl} a$ fluorescence transients even at concentration as low as $5 \mu \mathrm{M}$ of $\mathrm{Ag}^{+}$.

Chlorophyll $a$ fluorescence kinetics is affected by such factors as Chl content. Therefore, we evaluated the impact of $24 \mathrm{~h} \mathrm{Ag}^{+}$ 
TABLE 1 | Variations in $F_{\mathrm{o}}$ (the minimum fluorescence) and $F_{\mathrm{m}}$ (maximum fluorescence) of floating and submerged leaves of longleaf pondweed (Potamogeton nodosus) exposed to different concentrations of $\mathrm{AgNO}_{3}$.

\begin{tabular}{|c|c|c|c|c|}
\hline \multirow[t]{2}{*}{$\mathrm{Ag}^{+}(\mu \mathrm{M})$} & \multicolumn{2}{|c|}{$F_{\mathrm{o}}$} & \multicolumn{2}{|c|}{$F_{\mathrm{m}}$} \\
\hline & Floating & Submerged & Floating & Submerged \\
\hline 0 & $\begin{array}{c}302 \pm 29.6^{a} \\
(100)\end{array}$ & $\begin{array}{c}468 \pm 26.1^{a} \\
(100)\end{array}$ & $\begin{array}{c}1355 \pm 87.7^{a} \\
(100)\end{array}$ & $\begin{array}{c}1272 \pm 101.8^{a} \\
(100)\end{array}$ \\
\hline 5 & $\begin{array}{c}255 \pm 18.5^{\mathrm{a}} \\
(84.4)\end{array}$ & $\begin{array}{c}257 \pm 24.3^{b} \\
(54.9)\end{array}$ & $\begin{array}{c}936 \pm 68.3^{\mathrm{b}} \\
(69.1)\end{array}$ & $\begin{array}{c}377 \pm 21.1^{b} \\
(29.6)\end{array}$ \\
\hline 10 & $\begin{array}{c}238 \pm 21.6^{a b} \\
(78.8)\end{array}$ & $\begin{array}{c}253 \pm 19.7^{\mathrm{b}} \\
(54.1)\end{array}$ & $\begin{array}{c}549 \pm 39.9^{c} \\
(40.5)\end{array}$ & $\begin{array}{c}391 \pm 19.8^{b} \\
(30.7)\end{array}$ \\
\hline 50 & $\begin{array}{c}257 \pm 11.7^{\mathrm{a}} \\
(85.1)\end{array}$ & $\begin{array}{c}250 \pm 17.5^{\mathrm{b}} \\
(53.4)\end{array}$ & $\begin{array}{c}501 \pm 42.4^{c} \\
(36.9)\end{array}$ & $\begin{array}{c}299 \pm 23.7^{c} \\
(23.5)\end{array}$ \\
\hline 100 & $\begin{array}{c}213 \pm 13.3^{b} \\
(70.5)\end{array}$ & $\begin{array}{c}248 \pm 11.8^{\mathrm{b}} \\
(52.9)\end{array}$ & $\begin{array}{c}365 \pm 24.5^{d} \\
(26.9)\end{array}$ & $\begin{array}{c}311 \pm 28.5^{\mathrm{C}} \\
(24.4)\end{array}$ \\
\hline 250 & $\begin{array}{c}162 \pm 11.3^{\mathrm{C}} \\
(53.6)\end{array}$ & $\begin{array}{c}258 \pm 26.7^{b} \\
(55.1)\end{array}$ & $\begin{array}{c}160 \pm 11.1^{\mathrm{e}} \\
(11.8)\end{array}$ & $\begin{array}{c}245 \pm 16.9^{d} \\
(19.3)\end{array}$ \\
\hline 500 & $\begin{array}{c}152 \pm 11.1^{\mathrm{c}} \\
(50.3)\end{array}$ & $\begin{array}{c}142 \pm 11.5^{\mathrm{C}} \\
(30.3)\end{array}$ & $\begin{array}{c}144 \pm 8.9^{e} \\
(10.6)\end{array}$ & $\begin{array}{c}128 \pm 9.6^{e} \\
(10.1)\end{array}$ \\
\hline
\end{tabular}

Data are a mean of recordings from six independent experiments. Data represent mean \pm standard error. Values followed by the same small letter (in superscript) within a column do not differ significantly at $P \leq 0.05$ level (Duncan's multiple range test). Values in parenthesis represent the percent change over respective controls.

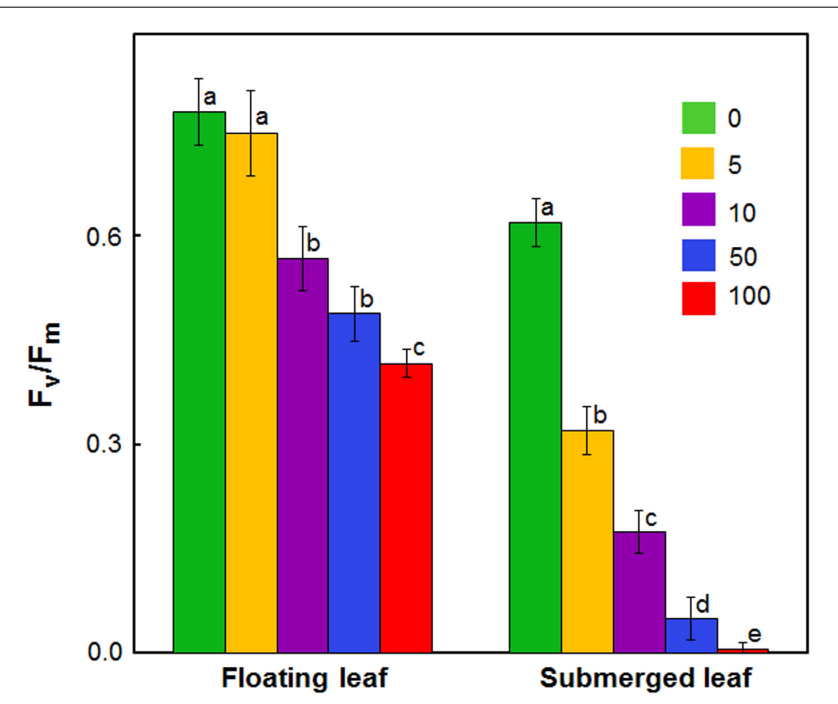

FIGURE 2 | Impact of $\mathrm{Ag}^{+}$on the quantum yield of Photosystem II activity (as inferred from $F_{\mathrm{v}} / F_{\mathrm{m}}$; see text) of floating and submerged leaves of longleaf pondweed ( $P$. nodosus) after $24 \mathrm{~h}$ exposure to varying concentrations of $\mathrm{AgNO}_{3}(\mu \mathrm{M})$. Data are a mean of recordings from six independent experiments. Vertical lines on data points represent standard errors. Different small letters over the bars reflects that the values recorded for leaves (floating or submerged) exposed to different concentrations of $\mathrm{AgNO}_{3}$ do not differ significantly at $P \leq 0.05$ level (Duncan's multiple range test).

treatment on both Chl $a$ and Chl $b$ levels. Decline of these Chls was recorded in both floating and submerged leaves, as a function of silver concentration (Table 2). However, the decline in the levels of both Chl $a$ and $\mathrm{Chl} b$ levels were significantly lower in the floating leaves. Interestingly, decline in levels of Chl $a$ was significantly higher than that of $\mathrm{Chl} b$ in both floating and submerged leaves.

Figure 4 depicts impact of $24 \mathrm{~h} \mathrm{Ag}^{+}$treatment on carboxylase activity of Rubisco in floating and submerged leaves. Upon exposure to $10 \mu \mathrm{M} \mathrm{Ag}{ }^{+}$, the carboxylase activity of Rubisco declined by $50 \%$ in the submerged leaves, whereas it remained unaltered in the floating ones. However, $100 \mu \mathrm{M} \mathrm{Ag}^{+}$caused $\sim 50$ and $\sim 90 \%$ decline in Rubisco activity in the floating and submerged leaves, respectively (Figure 4).

\section{Levels of $\mathrm{Ag}$ in Floating and Submerged Leaves}

Since there was a significant variation in the impact of $\mathrm{Ag}^{+}$ on photosynthetic efficiency between floating and submerged leaves, we measured $\mathrm{Ag}$ content in these leaves. Both floating and submerged leaves of longleaf pondweed exposed to $\mathrm{Ag}^{+}$ showed the presence of Ag. The level of $\mathrm{Ag}$ in these leaves increased as a function of $\mathrm{Ag}^{+}$concentration to which they were exposed (Figure 5A). At any $\mathrm{Ag}^{+}$concentration, silver content in submerged leaves was $\sim 3$ times higher than that in floating ones. XPS analysis also confirmed the presence of $\mathrm{Ag}$ in both leaves. XPS spectra showed two peaks at binding energies of 368 and $374 \mathrm{eV}$ (Figures 5B,C), which arise due to the emission of $3 \mathrm{~d}_{5 / 2}$ and $3 \mathrm{~d}_{3 / 2}$ photoelectrons, respectively (Adegboyega et al., 2013).

\section{Impact of $\mathrm{Ag}^{+}$on Antioxidant System in Floating and Submerged Leaves}

Like our earlier findings (Shabnam and Pardha-Saradhi, 2016), we did not observe any significant variation in the levels of ascorbate, phenolics, and thiols amongst floating and submerged leaves which were not exposed to $\mathrm{Ag}^{+}$. However, both floating and submerged leaves exposed to 10 and $100 \mu \mathrm{M} \mathrm{Ag}^{+}$showed a decline in the levels of all these three non-enzymatic antioxidants (Figure 6). Irrespective of the $\mathrm{Ag}^{+}$concentrations to which leaves were exposed, the decline in the level of phenolics was significantly higher in the submerged leaves (Figure 6A). However, the decline in the levels of ascorbate and thiols was almost similar for both leaves (Figures 6B,C).

Antioxidant enzymes, such as SOD, catalase (CAT), GPX, ascorbate peroxidase (APX), MDHAR, dehydroascorbate reductase (DHAR), and GR play an important role in scavenging ROS in plants exposed to heavy metals (Prasad et al., 1999; Dhir et al., 2009). Therefore, we evaluated the impact of $\mathrm{Ag}^{+}$on activities of these enzymes in both floating and submerged leaves of longleaf pondweed. $\mathrm{Ag}^{+}$treatment caused a significant decline in SOD activity in both floating and submerged leaves, although the decline was significantly higher in the latter compared to the former (Figure 7A). Both floating and submerged leaves, with the exception of floating leaves exposed to $10 \mu \mathrm{M} \mathrm{Ag}^{+}$, showed a significant decrease in the catalase activity compared to their respective controls (Figure $7 \mathbf{B}$ ). However, the degree of loss in catalase activity was higher in submerged leaves. Contrary to decreased activity of SOD and catalase, activity of GPX increased by 2-2.5-fold in submerged leaves exposed to $\mathrm{Ag}^{+}$(Figure 7C). However, floating leaves showed a decrease in GPX activity on exposure to $\mathrm{Ag}^{+}$. 

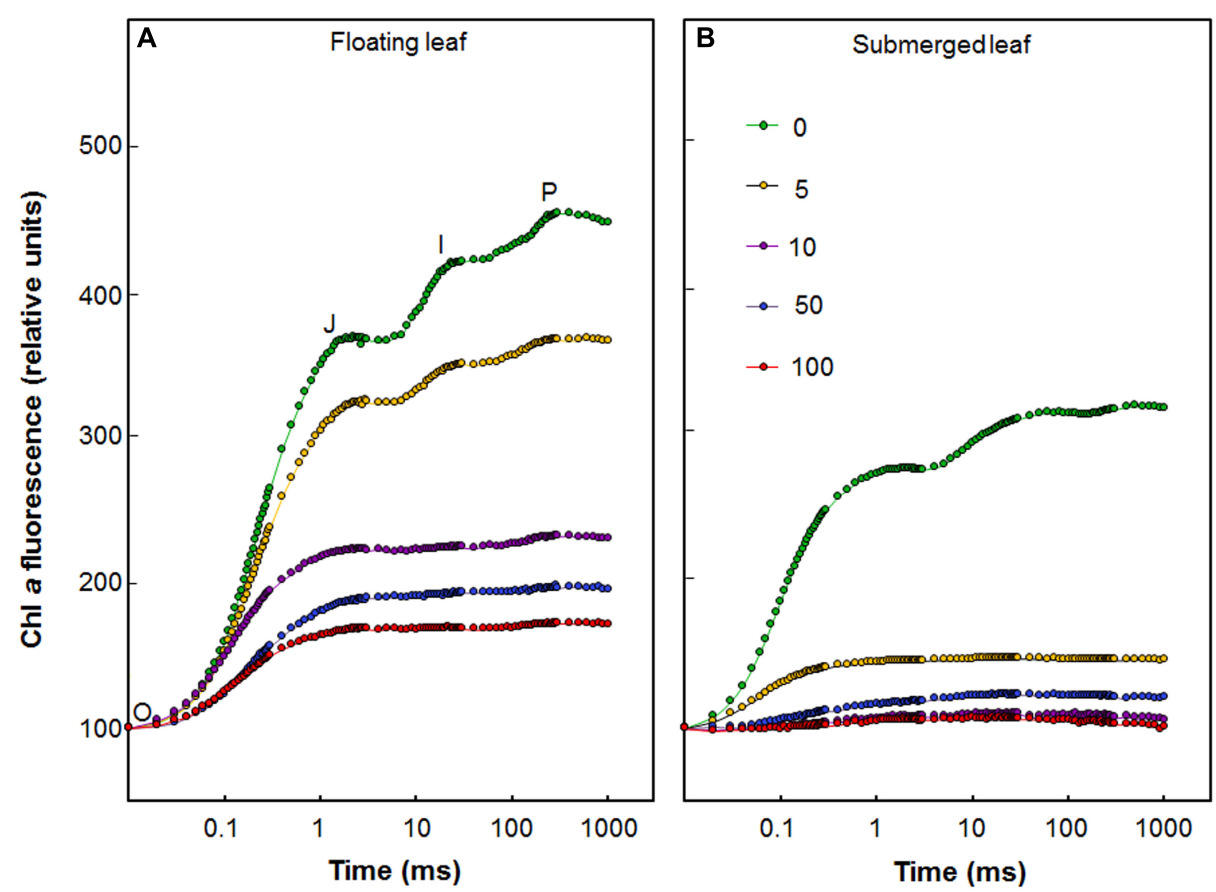

FIGURE 3 | Effect of $\mathrm{Ag}^{+}$on chlorophyll a fluorescence transient, the OJIP curve (see text), of floating and submerged leaves of longleaf pondweed (P. nodosus) after $24 \mathrm{~h}$ exposure to varying concentrations of $\mathrm{AgNO}_{3}$ (in $\left.\mu \mathrm{M}\right)$. Chl a fluorescence induction curves of floating (A) and submerged (B) leaves of longleaf pondweed exposed to varying concentrations of $\mathrm{AgNO}_{3}$ (in $\mu \mathrm{M}$ ) for $24 \mathrm{~h}$. Chl a fluorescence induction curves were plotted by normalizing data at the $F_{0}$ values.

TABLE 2 | Variation in Chl $a$ and Chl $b$ levels ( $\mu \mathrm{g} \mathrm{g}^{-1}$ fresh weight) in floating and submerged leaves of longleaf pondweed (P. nodosus) exposed to different concentrations of $\mathrm{AgNO}_{3}$.

\begin{tabular}{|c|c|c|c|c|}
\hline \multirow[t]{2}{*}{$\mathrm{Ag}^{+}(\mu \mathrm{M})$} & \multicolumn{2}{|c|}{ Chl a } & \multicolumn{2}{|c|}{ Chl $b$} \\
\hline & Floating & Submerged & Floating & Submerged \\
\hline 0 & $\begin{array}{c}626 \pm 33.3^{a} \\
(100)\end{array}$ & $\begin{array}{c}490 \pm 27.3^{a} \\
(100)\end{array}$ & $\begin{array}{c}492 \pm 21.5^{a} \\
(100)\end{array}$ & $\begin{array}{c}471 \pm 20.1^{\mathrm{a}} \\
(100)\end{array}$ \\
\hline 5 & $\begin{array}{c}598 \pm 28.9^{a} \\
(95.5)\end{array}$ & $\begin{array}{c}438 \pm 30.3^{a} \\
(89.4)\end{array}$ & $\begin{array}{c}486 \pm 26.7^{a} \\
(98.8)\end{array}$ & $\begin{array}{c}429 \pm 25.4^{a} \\
(91.1)\end{array}$ \\
\hline 10 & $\begin{array}{c}492 \pm 31.1^{b} \\
(78.6)\end{array}$ & $\begin{array}{c}368 \pm 23.7^{c} \\
(75.1)\end{array}$ & $\begin{array}{c}391 \pm 23.3^{b} \\
(79.4)\end{array}$ & $\begin{array}{c}367 \pm 26.7^{\mathrm{b}} \\
(77.9)\end{array}$ \\
\hline 50 & $\begin{array}{c}431 \pm 23.3^{b} \\
(68.8)\end{array}$ & $\begin{array}{c}298 \pm 16.9^{d} \\
(60.8)\end{array}$ & $\begin{array}{c}381 \pm 18.4^{b} \\
(77.4)\end{array}$ & $\begin{array}{c}342 \pm 19.5^{\mathrm{bc}} \\
(72.6)\end{array}$ \\
\hline 100 & $\begin{array}{c}401 \pm 23.5^{\mathrm{bc}} \\
(64.1)\end{array}$ & $\begin{array}{c}214 \pm 21.1^{\mathrm{e}} \\
(43.7)\end{array}$ & $\begin{array}{c}368 \pm 25.4^{\mathrm{bc}} \\
(74.7)\end{array}$ & $\begin{array}{c}273 \pm 20.3^{c} \\
(57.9)\end{array}$ \\
\hline 250 & $\begin{array}{c}369 \pm 19.7^{c} \\
(58.9)\end{array}$ & $\begin{array}{c}184 \pm 14.5^{\mathrm{e}} \\
(37.6)\end{array}$ & $\begin{array}{c}340 \pm 16.7^{\mathrm{c}} \\
(69.1)\end{array}$ & $\begin{array}{c}242 \pm 14.7^{\mathrm{c}} \\
(51.3)\end{array}$ \\
\hline 500 & $\begin{array}{c}227 \pm 20.8^{d} \\
(36.2)\end{array}$ & $\begin{array}{c}144 \pm 9.1^{f} \\
(29.4)\end{array}$ & $\begin{array}{c}298 \pm 17.4^{d} \\
(60.6)\end{array}$ & $\begin{array}{c}191 \pm 16.7^{d} \\
(40.5)\end{array}$ \\
\hline
\end{tabular}

Data are a mean of recordings from six independent experiments. Data represent mean \pm standard error. Values followed by same small letter (in superscript) within a column do not differ significantly at $P \leq 0.05$ level (Duncan's multiple range test). Values in parenthesis represent the percent change over respective controls.

Activities of enzymes of ascorbate-glutathione cycle, e.g., APX, MDHAR, DHAR, and GR, decreased significantly in both floating and submerged leaves as a function of given $\mathrm{Ag}^{+}$ level (Figure 8). In general, irrespective of the concentration of
$\mathrm{Ag}^{+}$used, the activities of ascorbate-glutathione cycle enzymes were significantly higher in floating leaves. Amongst enzymes of ascorbate-glutathione cycle, $\mathrm{Ag}^{+}$induced highest decrease in the activity of GR, followed by those of APX, MDHAR, and DHAR.

\section{DISCUSSION}

\section{Leaves of Longleaf Pondweed Generate Ag-NPs as a Defense Mechanism}

Earlier, Pardha-Saradhi et al. (2014a,b,c) reported that plants reduce toxic ionic forms of heavy metals into non/less-toxic NPs as a defense mechanism. During our investigations, we found that both floating and submerged leaves of longleaf pondweed could turn clear colorless $\mathrm{AgNO}_{3}$ solutions to colloidal brown (Figures 1A,B and Supplementary Figure 1). TEM coupled with SAED and EDX confirmed the presence of distinct crystalline NPs composed of Ag in these colloidal brown solutions (Figures 1C-F). However, similar to our earlier findings (PardhaSaradhi et al., 2014a), these brown colloidal solutions did not show any Ag-NP specific peak in the absorption spectra. In addition to SAED, PXRD confirmed the crystalline nature of Ag-NPs; PXRD pattern showed peaks specific to face centered cubic structured $\mathrm{Ag}^{0}$ and cubic structured $\mathrm{Ag}_{2} \mathrm{O}$. These PXRD analyses clearly showed that Ag-NPs generated by floating and submerged leaves are composed of both $\mathrm{Ag}^{0}$ and $\mathrm{Ag}_{2} \mathrm{O}$. XPS analysis confirmed the presence of $\mathrm{Ag}$ in both leaves and that the accumulated $\mathrm{Ag}$ in these leaves existed predominantly as 


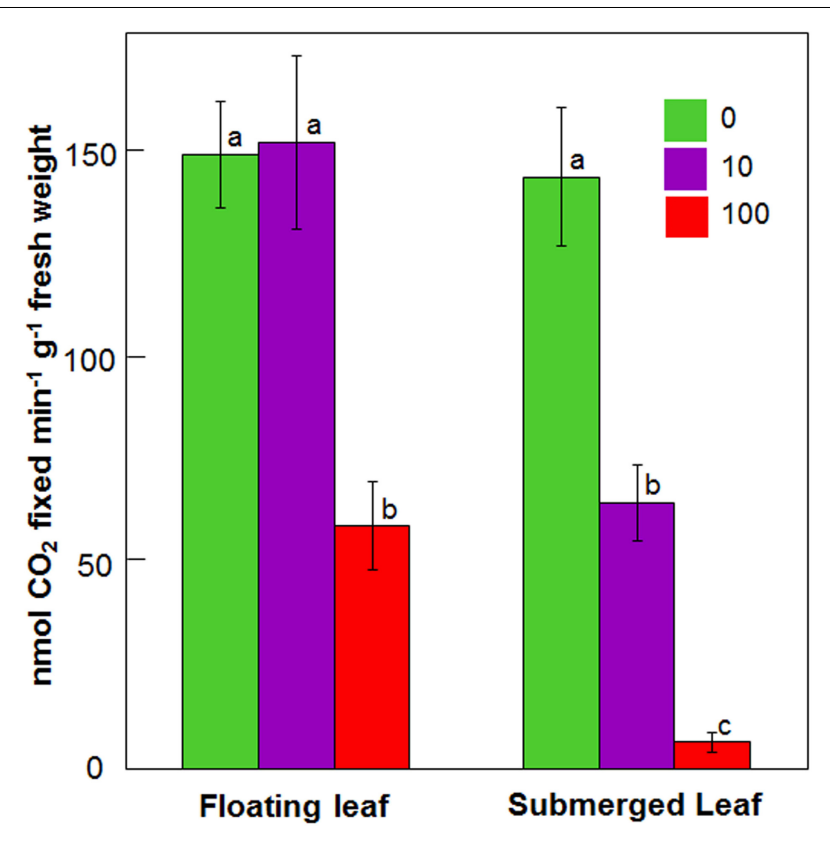

FIGURE 4 | Impact of $\mathrm{Ag}^{+}$on the carboxylase activity of Rubisco of floating and submerged leaves of longleaf pondweed ( $P$. nodosus) after $24 \mathrm{~h}$ exposure to 10 or $100 \mu \mathrm{M} \mathrm{AgNO}_{3}$. Data are a mean of recordings from six independent experiments. Vertical lines on bars represent standard errors. Different small letters over the bars reflect that the values recorded for leaves (floating or submerged) exposed to different concentrations of $\mathrm{AgNO}_{3}$ do not differ significantly at $P \leq 0.05$ level (Duncan's multiple range test).
$\mathrm{Ag}_{2} \mathrm{O}$ state. It is well-known that $\mathrm{Ag}^{0}$ and $\mathrm{Ag}^{0}$-NPs are prone to oxidation (Pardha-Saradhi et al., 2014a; Shabnam et al., 2016). Recently, Shabnam et al. (2016) demonstrated the potential of photosynthetic electron transport to reduce $\mathrm{Ag}^{+}$to $\mathrm{Ag}^{0}$ and to generate $\mathrm{Ag}^{0}$-NPs. They also specifically showed that $\mathrm{O}_{2}$ released as a byproduct during photosynthetic electron transport promotes oxidation of $\mathrm{Ag}^{0}$ and/or $\mathrm{Ag}^{0}$-NPs to generate $\mathrm{Ag}_{2} \mathrm{O}$ NPs. Therefore, we believe that $\mathrm{O}_{2}$ released by light harvesting photosynthetic machinery of leaves promotes oxidation of $\mathrm{Ag}^{0}$ and/or $\mathrm{Ag}^{0}$-NPs to generate $\mathrm{Ag}_{2} \mathrm{O}$-NPs.

As evident from the Supplementary Figure 1, only one side of floating leaves is in immediate contact with test solution and further, overall size (i.e., surface area) of submerged leaves is nearly double of floating leaves (Shabnam and Pardha-Saradhi, 2016). In spite of such a vast variation in the surface area in contact with the test solution, the color intensity of the $\mathrm{AgNO}_{3}$ solutions incubated with floating leaves was higher than the ones incubated with submerged leaves. This reveals superior potential of floating leaves to generate Ag-NPs compared to submerged leaves. Superior potential of floating leaves to generate Ag-NPs might be due to their superior photosynthetic photochemical reactions (Shabnam et al., 2015; Shabnam and Pardha-Saradhi, 2016).

Inductive coupled plasma analysis revealed that submerged leaves exposed to $\mathrm{Ag}^{+}$possessed 3-4 fold higher levels of silver than floating leaves, which discloses that the uptake of Ag by the former leaves is significantly higher than the latter leaves. Higher levels of Ag in submerged leaves can be accounted to (i) larger surface area (as detailed above) available for uptake of Ag; and (ii) lower potential to reduce $\mathrm{Ag}^{+}$and generate $\mathrm{Ag}-\mathrm{NPs}$, compared to floating leaves. We have recently demonstrated that the uptake of Ag by plants of Spirodela polyrhiza in the ionic state is 3-4 times higher than in the NP state (Shabnam et al., 2017). Therefore, we believe that superior potential to efficiently reduce $\mathrm{Ag}^{+}$and generate Ag-NPs is one of the mechanisms acquired by floating leaves to curb the uptake of Ag.

\section{Floating Leaves Possess Superior Potential to Protect Photosynthetic Machinery Against $\mathrm{Ag}^{+}-$Toxicity Than Submerged Leaves}

Photosystem II plays a vital role in photochemical reactions. Accordingly, overall photosynthetic capacity of plants often relies on PS II activity (Shabnam et al., 2015). Therefore, during the present investigations, we evaluated the impact of $\mathrm{Ag}^{+}$on PS II efficiency. $F_{\mathrm{v}} / F_{\mathrm{m}}$ is a commonly used parameter to determine Photosystem II efficiency of plants (Strasser et al., 1995; Stirbet and Govindjee, 2012). PS II efficiency, measured in terms of $F_{\mathrm{V}} / F_{\mathrm{m}}$ as well as through $\mathrm{Chl} a$ fluorescence kinetics, was significantly higher in floating leaves compared to submerged leaves, just as in our earlier findings (Shabnam et al., 2015).

In this paper, we found that $\mathrm{Ag}^{+}$caused a significant decline in PS II efficiency of both floating and submerged leaves of longleaf pondweed. $\mathrm{Ag}^{+}$-induced decline in the quantum yield of PS II activity has also been reported in submerged P. crispus, as well as in free floating S. polyrhiza (Xu et al., 2010; Jiang et al., 2012; Shabnam et al., 2017). However, $\mathrm{Ag}^{+}$-induced suppression in PS II efficiency was significantly lower in the floating leaves compared to that in the submerged leaves. These findings unequivocally demonstrate the prevalence of superior mechanism(s) in floating leaves to counter $\mathrm{Ag}^{+}$.

As mentioned earlier, all oxygen-evolving organisms show polyphasic Chl a fluorescence transients with distinct O-J, $\mathrm{J}-\mathrm{I}$, and I-P photochemical phases (Figure 3). While $\mathrm{O}-\mathrm{J}$ rise (0.05-2 ms) involves the reduction of $\mathrm{Q}_{\mathrm{A}}$ to $\mathrm{Q}_{\mathrm{A}}{ }^{-}$, the J-I rise (2-30 ms) denotes reduction of PQ pool and the I-P rise (30-300 ms) implies reduction of the acceptor side of PS I (Strasser et al., 1995; Stirbet and Govindjee, 2012; Hamdani et al., 2015; Shabnam et al., 2015, 2017). The OJIP transient kinetics are highly sensitive to various stresses including heavy metal stress (Appenroth et al., 2001; Oukarroum et al., 2012; Shabnam et al., 2015, 2017). During this study, we observed a drastic negative impact of $\mathrm{Ag}^{+}$on the OJIP transients in longleaf pondweed leaves, even at a concentration of $5 \mu \mathrm{M}$. Negative impact of $\mathrm{Ag}^{+}$on the OJIP transients was significantly higher in the submerged leaves. As shown in Figure 3, while floating leaves retain polyphasic nature of the OJIP transients, the submerged leaves showed a complete loss in the polyphasic nature of this transient on exposure to $5 \mu \mathrm{M} \mathrm{Ag}^{+}$. Severe loss in fluorescence intensity or polyphasic nature of OJIP transients has also been observed in several algae and plants exposed to heavy metals (Appenroth et al., 2001; Oukarroum et al., 2012; Wang et al., 2014; Shabnam et al., 2017). There are reports 

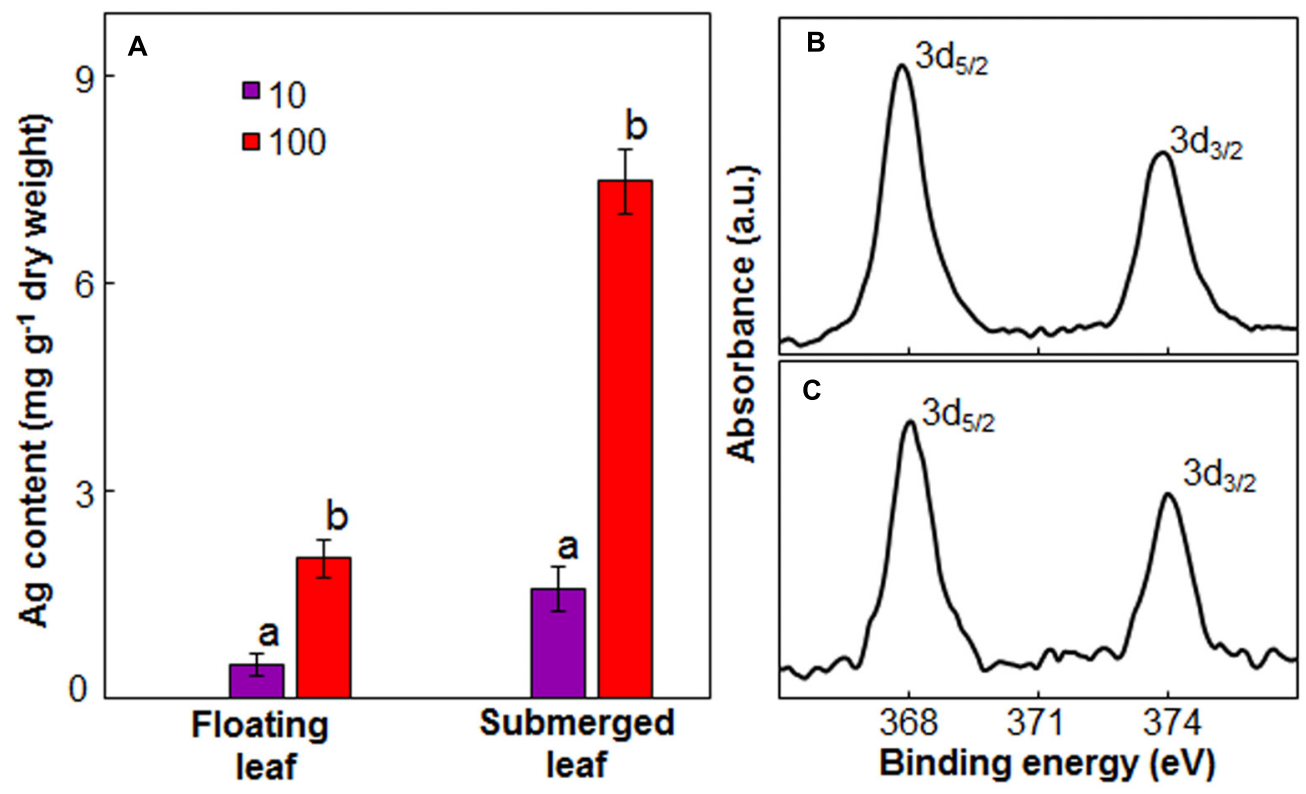

FIGURE 5 | Ag content in floating and submerged leaves of longleaf pondweed (P. nodosus) after 24 h exposure to 10 or 100 $\mu$ M AgNO 3 . (A) Bars are a mean of data from three independent experiments for different treatments. Vertical lines on data points represent standard errors. Different small letters over the bars reflect that the values recorded for leaves (floating or submerged) exposed to different concentrations of $\mathrm{AgNO}_{3}$ do not differ significantly at $P \leq 0.05$ level (Duncan's multiple range test). High resolution XPS $(\mathbf{B}, \mathbf{C})$ of floating $\mathbf{( B )}$ and submerged $\mathbf{( C )}$ leaves showing presence of peaks specific to $\mathrm{Ag} 2 \mathrm{O}$.
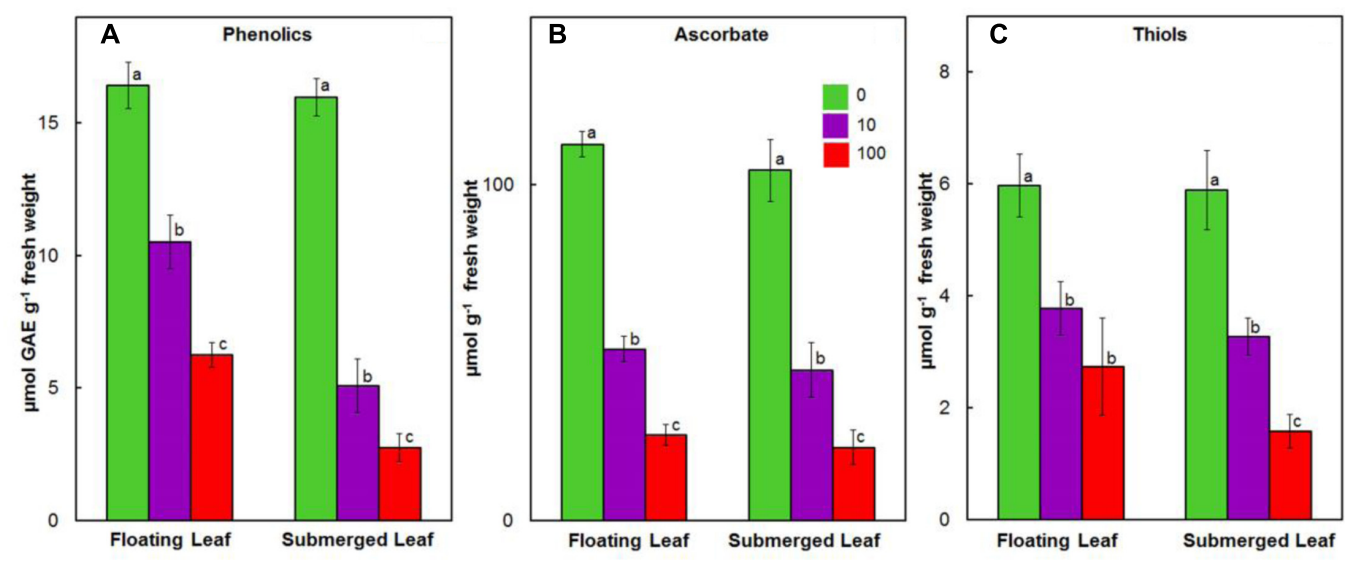

FIGURE 6 | Impact of $\mathrm{Ag}^{+}$on the levels of non-enzymatic antioxidants. Levels of phenolics (A); ascorbate (B); and thiols (C) in floating and submerged leaves of longleaf pondweed ( $P$. nodosus) after $24 \mathrm{~h}$ exposure to 10 or $100 \mu \mathrm{M} \mathrm{AgNO}_{3}$. Bars are a mean of data from six independent experiments for different treatments. Vertical lines on bars represent standard errors. Different small letters over the bars reflect that the values recorded for leaves (floating or submerged) exposed to different concentrations of $\mathrm{AgNO}_{3}$ do not differ significantly at $P \leq 0.05$ level (Duncan's multiple range test).

of inhibition of the oxygen evolving complex (OEC) by metal ions such as Cd and Cr (see e.g., Atal et al., 1991). Severe negative impact of $\mathrm{Ag}^{+}$on the OJIP transients during this study suggests that $\mathrm{Ag}^{+}$could be inhibiting the OEC of PSII as well as the flow of electrons from $\mathrm{QA}^{-}$to the electron acceptor side of PS I (via the PQ-pool), in both floating and submerged leaves of longleaf pondweed. Higher Ag content in submerged leaves could be responsible for a significantly higher decline in their photosynthetic efficiency, compared to that of floating leaves.
As noted earlier, Chl $a$ fluorescence kinetics can be affected by such factors like Chl content. A 24-h $\mathrm{Ag}^{+}$treatment caused a decline in the levels of Chl $a$ and $\mathrm{Chl} b$ in a concentrationdependent manner, in both floating and submerged leaves (Table 2). However, the decline in the levels of both Chl $a$ and Chl $b$ were significantly lower in the floating leaves. Our present findings clearly demonstrate that floating leaves are better equipped to protect their photosynthetic machinery against $\mathrm{Ag}^{+}$toxicity than submerged leaves. Superior potential of the floating leaves to withstand $\mathrm{Ag}^{+}$induced suppression of photosynthetic 

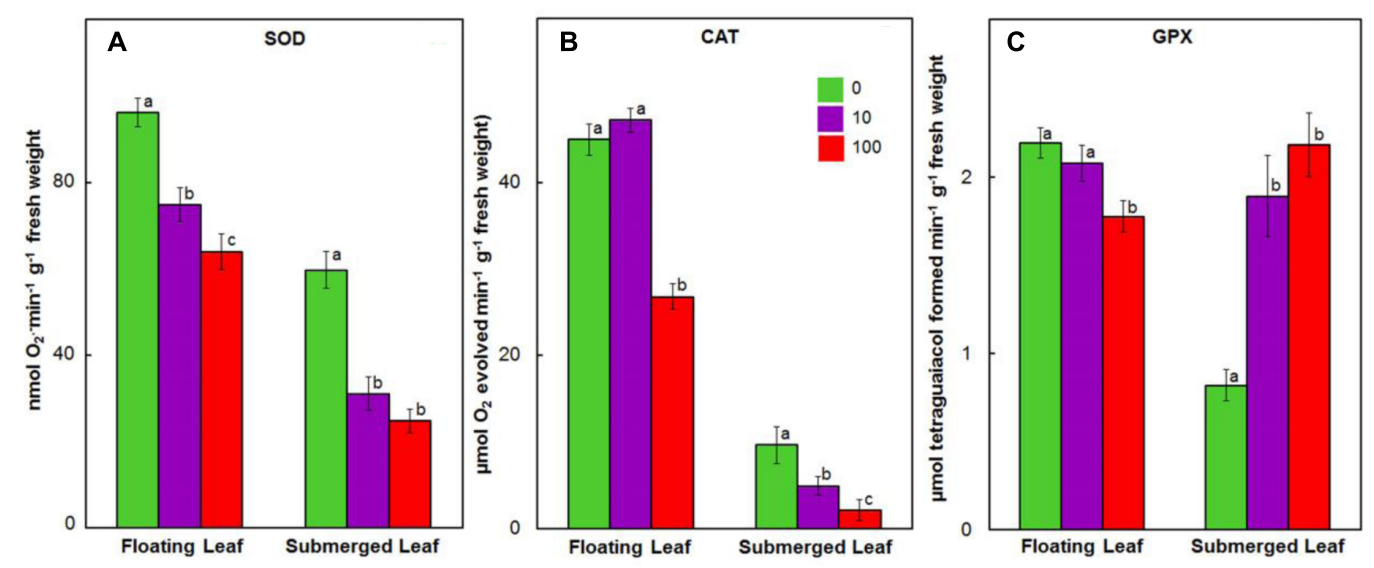

FIGURE 7 | Impact of $\mathrm{Ag}^{+}$on the activities of antioxidant enzymes. Activity of SOD (A); catalase (CAT) (B), and guaiacol peroxidase (GPX) (C) in floating and submerged leaves of longleaf pondweed (P. nodosus) after $24 \mathrm{~h}$ exposure to 10 or $100 \mu \mathrm{M} \mathrm{AgNO}$. Bars are a mean of data from six independent experiments for different treatments. Vertical lines on data points represent standard errors. Different small letters over the bars reflect that the values recorded for leaves (floating or submerged) exposed to different concentrations of $\mathrm{AgNO}_{3}$ do not differ significantly at $P \leq 0.05$ level (Duncan's multiple range test).
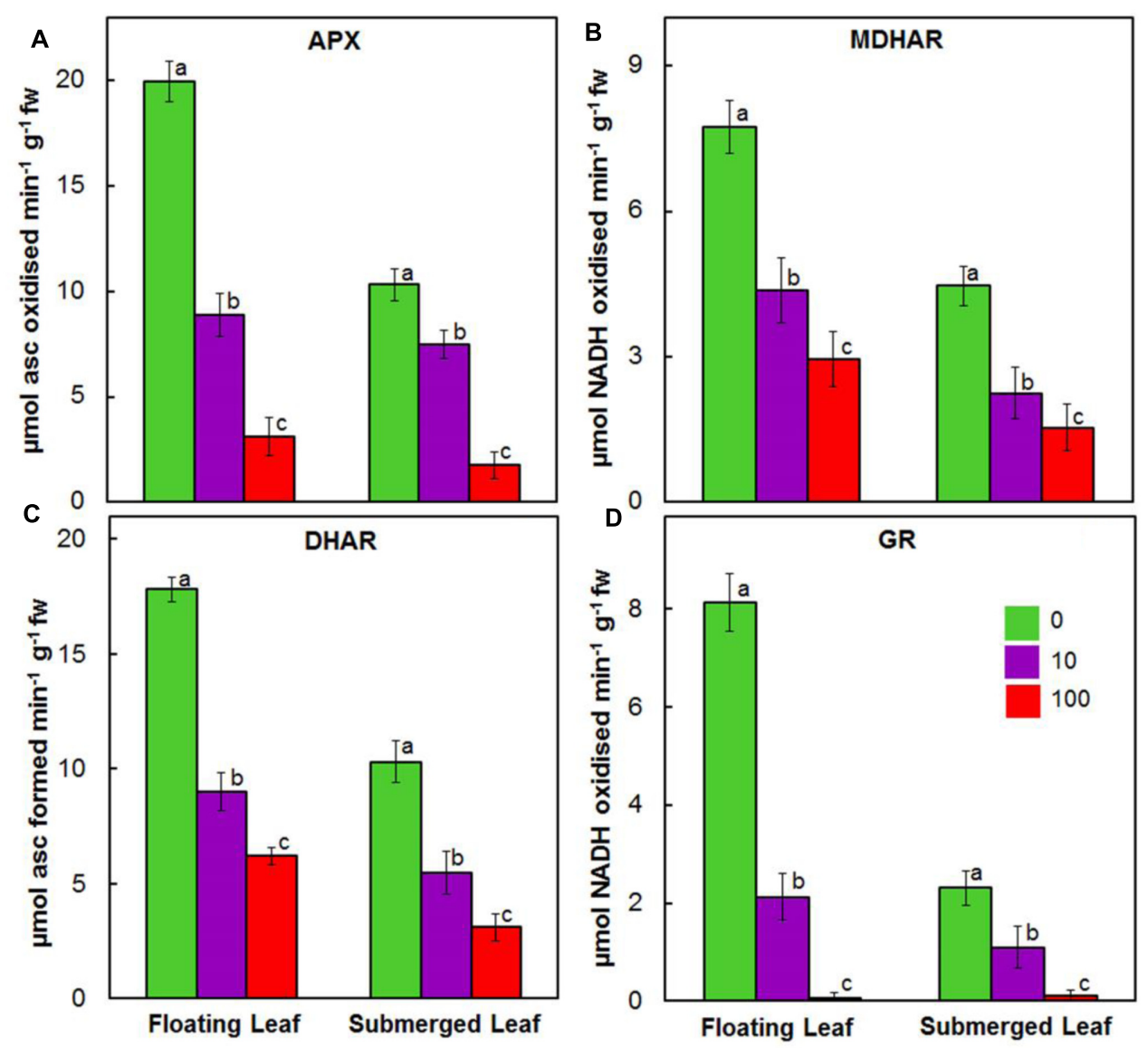

FIGURE 8 | Impact of $\mathrm{Ag}^{+}$on the activities of antioxidant enzymes of ascorbate-glutathione cycle. Activity of ascorbate peroxidase (APX) (A);

monodehydroascorbate reductase (MDHAR) (B); dehydroascorbate reductase (DHAR) (C); and glutathione reductase (GR) (D) in floating and submerged leaves of longleaf pondweed (P. nodosus) after $24 \mathrm{~h}$ exposure to 10 or $100 \mu \mathrm{M} \mathrm{AgNO}_{3}$. Data are a mean of recordings from six independent experiments. Vertical lines on data points represent standard errors. Different small letter over the bars reflects that the values recorded for leaves (floating or submerged) exposed to different concentrations of $\mathrm{AgNO}_{3}$ do not differ significantly at $P \leq 0.05$ level (Duncan's multiple range test). 


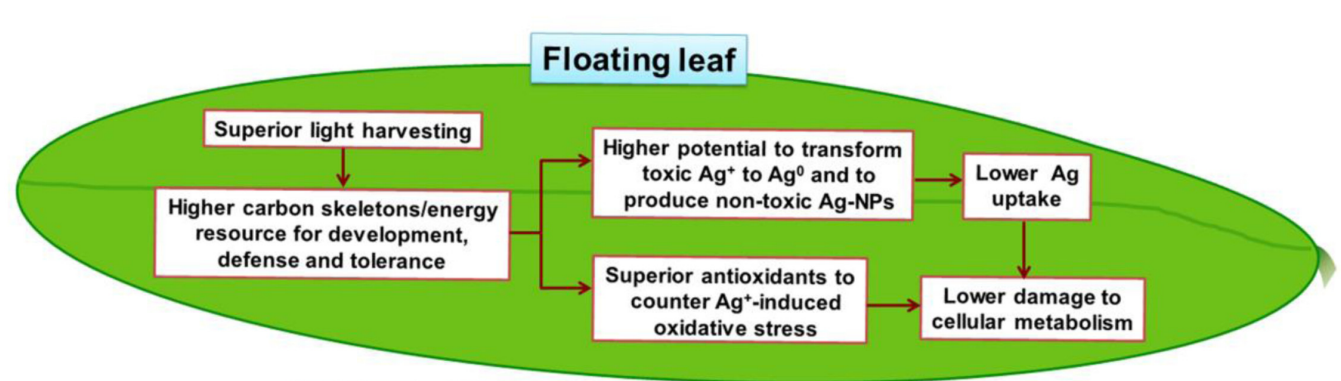

Higher tolerance to withstand heavy metal stress

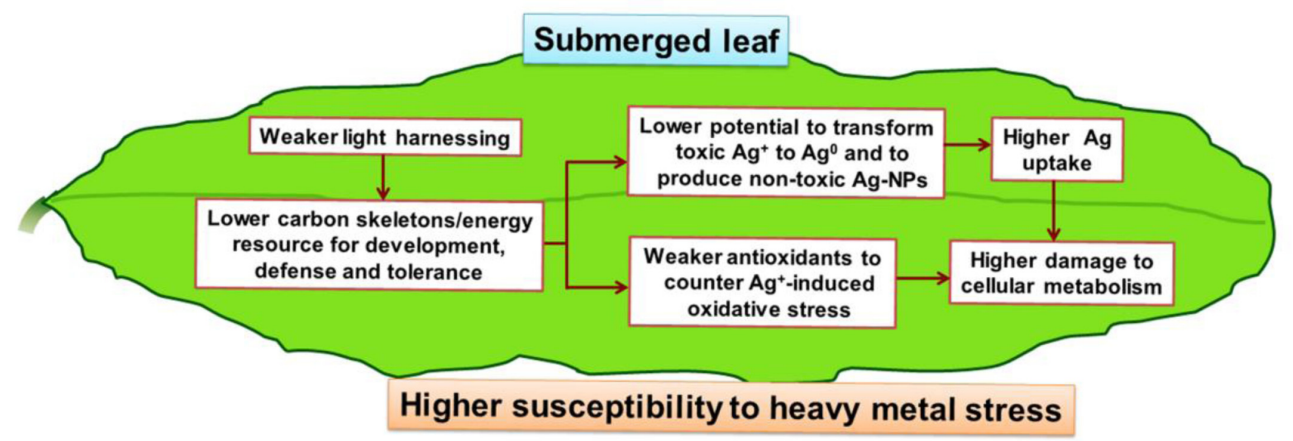

FIGURE 9 | A hypothetical model depicting the key metabolic events in floating and submerged leaves of longleaf pondweed (P. nodosus) influenced by $\mathrm{Ag}^{+}$-stress. Note that the superior photosynthesis enables floating leaf to be better equipped with carbon skeletons and energy resources required to counter heavy metal stress than submerged leaves.

efficiency could be due to (i) higher potential to reduce $\mathrm{Ag}^{+}$to Ag-NPs at the surface, and (ii) restricted uptake of Ag compared to submerged leaves.

In spite of having similar carboxylase activity of Rubisco, the control submerged leaves possess lesser carbon skeletons compared to the control floating leaves. Higher carbon skeletons in floating leaves is due to significantly higher and efficient light harvesting photochemical reactions (pivotal for the generation of assimilatory power essential for $\mathrm{CO}_{2}$ fixation and the synthesis of various carbon skeletons). Lower decline in carboxylase activity of Rubisco in floating leaves revealed that floating leaves are better equipped to protect the carboxylase activity of Rubisco than submerged leaves.

Decline in the carboxylase activity of Rubisco has been reported earlier in terrestrial plants, such as Phaseolus vulgaris, Zea mays, Oryza sativa, and Citrus grandis, exposed to $\mathrm{Zn}, \mathrm{Cd}$, and Mn (Van Assche and Clijsters, 1986; Krantev et al., 2008; Li et al., 2010; Wang et al., 2014) and aquatic plants, such as Salvinia natans and Ceratopteris pteridoides, exposed to $\mathrm{Cr}$ and Cd (Dhir et al., 2008; Deng et al., 2014). $\mathrm{Ag}^{+}$induced decline in PS II efficiency and carboxylase activity of Rubisco of these plants may be due to (i) ROS induced inactivation (Sharma and Dietz, 2009; Foyer and Noctor, 2016), (ii) enhanced proteolytic activity (Hajduch et al., 2001; Gajewska et al., 2013), (iii) interference with enzyme's structure by substitution of native ions (Van Assche and Clijsters, 1986) and/or interaction with SH groups (e.g., by
$\mathrm{Cu}$ and Cd) (Stiborova, 1998; Stiborova et al., 1998), and (iv) impaired protein biosynthesis (Kremer and Markham, 1982). A simple comparison of the impact of $\mathrm{Ag}^{+}$on PSII efficiency with carboxylase activity of Rubisco reveals that the light harvesting photochemical reactions are more sensitive to $\mathrm{Ag}^{+}$than carbon fixation reactions.

\section{Superior Antioxidant System of Floating Leaves Counters $\mathrm{Ag}^{+}$-Toxicity}

In general, heavy metals promote generation of ROS by interfering with electron transport and redox reactions (Prasad et al., 1999; Hall, 2002; Metwally et al., 2003; Sharma and Dietz, 2009; Pardha-Saradhi et al., 2014b). Accordingly, plants have evolved antioxidant systems, both non-enzymatic and enzymatic, to counter oxidative stress (Prasad et al., 1999; Shabnam and Pardha-Saradhi, 2016). Amongst the nonenzymatic antioxidants, ascorbate, phenolics and thiols play important roles in scavenging ROS and/or chelating heavy metals (Sakihama et al., 2002; Shabnam et al., 2014; Shabnam and Pardha-Saradhi, 2016). Plants exposed to heavy metal ions, such as $\mathrm{Cd}, \mathrm{Pb}$, and $\mathrm{Zn}$, show enhanced levels of non-enzymatic antioxidants (Prasad et al., 1999; Oncel et al., 2000; Mishra et al., 2006). On the contrary, we observed a decline in the levels of all the non-enzymatic antioxidants in both floating and submerged leaves exposed to $\mathrm{Ag}^{+}$(Figure 6). Significantly lower $\mathrm{Ag}^{+}$-induced decline in the content of phenolics in floating 
leaves could be one of the factors contributing to their superior potential to withstand $\mathrm{Ag}^{+}$-stress. Posmyk et al. (2009) also reported a decline in the phenolic content in red cabbage under $\mathrm{Cu}$ stress. A significant decline in the levels of ascorbate and/or thiols/GSH has been reported in studies with (i) submerged P. crispus plants exposed to $\mathrm{Ag}^{+}$(Xu et al., 2010); (ii) pigeon pea seedlings exposed to $\mathrm{Ni}^{2+}$ and $\mathrm{Zn}^{2+}$ (Rao and Sresty, 2000); (iii) roots of soybean exposed to $\mathrm{Cd}^{2+}$ (Balestrasse et al., 2001); and (iv) roots and shoots of maize exposed to $\mathrm{Cd}^{2+}$ (Tukendorf and Rauser, 1990; Meuwly and Rauser, 1992). $\mathrm{Ag}^{+}$has a strong affinity for thiols (Rao and Sresty, 2000; Blaske et al., 2013) like other heavy metals. A positive correlation has been established between the depletion of thiol content and the amount of metal ions $\left(\mathrm{Cu}^{2+}, \mathrm{Zn}^{2+}\right)$ accumulated by plants (Tripathi et al., 2006). Thus, a decline in the levels of thiols, shown in this study, could be due to the binding of thiols to $\mathrm{Ag}^{+}$. In general, decrease in the levels of non-enzymatic antioxidants could be due to (i) enhanced catabolic degradation, (ii) alteration in their structure via chelation or reduction of metal ions, and/or (iii) decreased biosynthesis.

Significantly higher activities of antioxidant enzymes in floating leaves impart superior potential to counter oxidative damage compared to submerged leaves. $\mathrm{Ag}^{+}$induced a significant decline in activity of SOD and catalase in both floating and submerged leaves; the decline was significantly higher in the latter (Figure 7A). Contrary to the decreased activity of SOD and catalase, the activity of GPX increased by $2-2.5$-fold in the submerged leaves exposed to $\mathrm{Ag}^{+}$(Figure 7C). However, the floating leaves showed a decrease in GPX activity on exposure to $\mathrm{Ag}^{+}$. In contrast to the decline in the activities of SOD and catalase, and an increase in GPX activity recorded in the submerged leaves of longleaf pondweed (present study), Xu et al. (2010) noted increase in activities of SOD and catalase, and a decline in the activity of GPX in submerged P. crispus, exposed to $\mathrm{Ag}^{+}$. Salvinia natans exposed to $\mathrm{Cr}$-rich water, however, showed an increase in GPX activity, without any significant alteration in CAT activity (Dhir et al., 2009). Interestingly, Shah et al. (2001) also noted enhancement of GPX activity accompanied with a decline in CAT activity in rice exposed to cadmium. Peroxidases play a significant role in the synthesis of lignin, which is impermeable to metal ions (Hegedüs et al., 2001; Parrotta et al., 2015). Therefore, we believe that an increased GPX activity in submerged leaves might be a strategy to restrict the uptake of $\mathrm{Ag}^{+}$.

Silver ions also suppressed activities of enzymes of the ascorbate glutathione cycle in both types of the leaves. $\mathrm{Ag}^{+}$ induced decline in the activities of antioxidant enzymes in both floating and submerged leaves, except GPX in the submerged leaves, which is in agreement with those measured in the roots of soybean and poplar exposed to $\mathrm{Cd}^{2+}$ (Balestrasse et al., 2001; Schutzendubel et al., 2002). A similar decline in the activities of several antioxidant enzymes was observed in cotyledons and leaves of sunflower seedlings under $\mathrm{Cd}^{2+}, \mathrm{Fe}^{2+}$, and $\mathrm{Cu}^{2+}$ stress (Gallego et al., 1996a,b). In addition, the potential of $\mathrm{Ag}^{+}$to displace native metal cations from their usual binding sites in enzymes has been reported (Ghandour et al., 1988). $\mathrm{Ag}^{+}$induced decline in the activity of the antioxidant enzymes might be due to the effect of $\mathrm{Ag}^{+}$on expression of the relevant genes at the transcriptional/translational level by binding with DNA/RNA. Further, this effect might be at the post-translational level. The binding of $\mathrm{Ag}^{+}$to $\mathrm{SH}$ and other active groups might alter 3-D structure of these antioxidant enzymes affecting the catalytic/active site(s) vital for their activities (Ghandour et al., 1988).

A summary of the differential impacts of $\mathrm{Ag}^{+}$on the floating and the submerged leaves of longleaf pondweed is presented in a hypothetical model (Figure 9). Superior photosynthesis in floating leaves leads to production of more carbon skeletons and energy resources compared to that in submerged leaves. Accordingly, floating leaves are better equipped to counter/tolerate stress imposed by heavy metals, such as $\mathrm{Ag}^{+}$. This includes (i) a superior capacity to biotransform toxic ionic state of heavy metals (such as $\mathrm{Ag}^{+}$) into less/nontoxic NPs (such as $\mathrm{Ag}^{0} / \mathrm{Ag}_{2} \mathrm{O}-\mathrm{NPs}$ ); and (ii) a better capacity to counter oxidative stress through a superior antioxidant system. In addition, significantly higher levels of Ag accumulated in submerged leaves would also directly interfere with their cellular metabolism.

\section{CONCLUSION}

In this paper, we have demonstrated for the first time that the floating leaves of longleaf pondweed possess a significantly higher potential to withstand $\mathrm{Ag}^{+}$-toxicity compared to that in the submerged leaves due to (i) superior photosynthetic machinery and an antioxidant system, (ii) superior potential to reduce $\mathrm{Ag}^{+}$ to $\mathrm{Ag}^{0}$ and generate $\mathrm{Ag}-\mathrm{NPs}\left(\mathrm{Ag}^{0} / \mathrm{Ag}_{2} \mathrm{O}-\mathrm{NPs}\right)$ on their surface; and (iii) superior potential to restrict uptake of Ag. Our findings suggest that any effort made to increase the proportion of floating leaves to the submerged leaves in longleaf pondweed would be beneficial for apt detoxification of water bodies contaminated with heavy metal ions.

\section{AUTHOR CONTRIBUTIONS}

The conception or design of the work: PP-S, NS, and HK. The acquisition, analysis: NS, PS, PP-S, and HK. Interpretation of data for the work: NS, PS, PP-S, HK, and G. Drafting the work: NS, PS, and PP-S. Revising it critically for important intellectual content: NS, PS, PP-S, HK, and G. Final approval of the version to be published: NS, PS, PP-S, HK, and G. Agreement to be accountable for all aspects of the work in ensuring that questions related to the accuracy or integrity of any part of the work are appropriately investigated and resolved: NS, PS, PP-S, HK, and $\mathrm{G}$.

\section{FUNDING}

This study was supported by Department of Biotechnology, Ministry of Science and Technology [Award Number: BT/Bio-CARe/02/604/2011-12 (PS)]; University of Delhi [Award 
Number: RC/2015/9677 (PP-S)]; Korea Environmental Industry and Technology Institute [Award Number: 2015001790002 $(\mathrm{HK})]$.

\section{ACKNOWLEDGMENTS}

Financial support from the Department of Biotechnology (Government of India), University of Delhi and the Korea Environmental Industry and Technology Institute is gratefully

\section{REFERENCES}

Adegboyega, N. F., Sharma, V. K., Siskova, K., Zbořil, R., Sohn, M., Schultz, B. J., et al. (2013). Interactions of aqueous $\mathrm{Ag}^{+}$with fulvic acids: mechanisms of silver nanoparticle formation and investigation of stability. Environ. Sci. Technol. 47, 757-764. doi: 10.1021/es302305f

Appenroth, K.-J., Stockel, J., Srivastava, A., and Strasser, R. J. (2001). Multiple effects of chromate on the photosynthetic apparatus of Spirodela polyrhiza as probed by OJIP chlorophyll $a$ fluorescence measurements. Environ. Pollut. 115, 49-64. doi: 10.1016/S0269-7491(01)00091-4

Arnon, D. I. (1949). Copper enzymes in isolated chloroplasts. Polyphenol oxidase in Beta vulgaris. Plant Physiol. 24, 1-15. doi: 10.1104/pp.24.1.1

Arrigo, K. R. (2005). Marine microorganisms and global nutrient cycles. Nature 437, 349-355. doi: 10.1038/nature04159

Atal, N., Pardha-Saradhi, P., and Mohanty, P. (1991). Inhibition of the chloroplast photochemical reactions by treatment of wheat seedlings with low concentrations of cadmium: analysis of electron transport activities and changes in fluorescence yield. Plant Cell Physiol. 32, 943-951. doi: 10.1093/ oxfordjournals.pcp.a078181

Balestrasse, K. B., Gardey, L., Gallego, S. M., and Tomaro, M. L. (2001). Response of antioxidant defence system in soybean nodules and roots subjected to cadmium stress. Aust. J. Plant Physiol. 28, 497-504. doi: 10.1007/s10534-008-9132-0

Blaske, F., Stork, L., Sperling, M., and Karst, U. (2013). Adduct formation of ionic and nanoparticular silver with amino acids and glutathione. J. Nanopart. Res. 15:1928. doi: 10.1007/s11051-013-1928-3

Deng, G., Li, M., Li, H., Yin, L., and Li, W. (2014). Exposure to cadmium causes declines in growth and photosynthesis in the endangered aquatic fern (Ceratopteris pteridoides). Aquat. Bot. 112, 23-32. doi: 10.1016/j.aquabot.2013. 07.003

Dhir, B., Sharmila, P., and Pardha-Saradhi, P. (2008). Photosynthetic performance of Salvinia natans exposed to chromium and zinc rich wastewater. Braz. J. Plant Physiol. 20, 61-70. doi: 10.1590/S1677-04202008000100007

Dhir, B., Sharmila, P., and Pardha-Saradhi, P. (2009). Potential of aquatic macrophytes for removing contaminants from the environment. Crit. Rev. Environ. Sci. Technol. 39, 754-781. doi: 10.1007/s10661-012-2873-9

Foyer, C. H., and Noctor, G. (2016). Stress-triggered redox signalling: What's in pROSpect? Plant Cell Environ. 39, 951-964. doi: 10.1111/pce.12621

Gajewska, E., Niewiadomska, E., Tokarz, K., Słaba, M., and Skłodowska, M. (2013). Nickel-induced changes in carbon metabolism in wheat shoots. J. Plant Physiol. 170, 369-377. doi: 10.1016/j.jplph.2012.10.012

Gallego, S. M., Benavides, M. P., and Tomaro, M. L. (1996a). Effect of cadmium ions on antioxidant defense system in sunflower cotyledons. Biol. Plant. 42, 49-55. doi: 10.1023/A:1002159123727

Gallego, S. M., Benavides, M. P., and Tomaro, M. L. (1996b). Effect of heavy metal ion excess on sunflower leaves: evidence for involvement of oxidative stress. Plant Sci. 121, 151-159. doi: 10.1016/S0168-9452(96)04528-1

Ghandour, W., Hubbard, J. A., Deistung, J., Hughes, M. N., and Poole, R. K. (1988). The uptake of silver ions by Escherichia coli K12: toxic effects and interaction with copper ions. Appl. Microbiol. Biotechnol. 28, 559-565. doi: 10.1007/BF00250412

Govindjee (2004). "Chlorophyll a fluorescence: a bit of basics and history," in Chlorophyll a Fluorescence: A Signature of Photosynthesis. Advances in Photosynthesis and Respiration, Vol. 19, eds G. C. Papageorgiou and Govindjee (Dordrecht: Springer), 1-42. doi: 10.1007/978-1-4020-3218-9_1 acknowledged. G thanks the Departments of Biochemistry and Plant Biology, University of Illinois at Urbana-Champaign for support.

\section{SUPPLEMENTARY MATERIAL}

The Supplementary Material for this article can be found online at: http://journal.frontiersin.org/article/10.3389/fpls.2017.01052/ full\#supplementary-material

Hajduch, M., Rakwal, R., Agrawal, G. K., Yonekura, M., and Pretova, A. (2001). High-resolution two-dimensional electrophoresis separation of proteins from metal-stressed rice (Oryza sativa L.) leaves: drastic reductions/fragmentation of ribulose-1,5-bisphosphate carboxylase/oxygenase and induction of stress related proteins. Electrophoresis 22, 2824-2831. doi: 10.1002/1522-2683(200108)22:13<2824::AID-ELPS2824>3.0.CO;2-C

Hall, J. L. (2002). Cellular mechanisms for heavy metal detoxification and tolerance. J. Exp. Bot. 53, 1-11. doi: 10.1093/jxb/53.366.1

Hamdani, S., Qu, M., Xin, C.-P., Li, M., Chu, C., Govindjee, et al. (2015). Variations between the photosynthetic properties of elite and landrace Chinese rice cultivars revealed by simultaneous measurements of $820 \mathrm{~nm}$ transmission signal and Chlorophyll $a$ fluorescence induction. J. Plant Physiol. 177, 128-138. doi: 10.1016/j.jplph.2014.12.019

Hegedüs, A., Erdei, S., and Horváth, G. (2001). Comparative studies of H2O2 detoxifying enzymes in green and greening barley seedlings under cadmium stress. Plant Sci. 160, 1085-1093. doi: 10.1016/S0168-9452(01)00330-2

Iida, S., Miyagi, A., Aoki, S., Ito, M., Kadono, Y., and Kosuge, K. (2009). Molecular adaptation of rbcL in the heterophyllous aquatic plant Potamogeton. PLoS ONE 4:e4633. doi: 10.1371/journal.pone.0004633

Jiang, H. S., Li, M., Chang, F.-Y., Li, W., and Yin, L. Y. (2012). Physiological analysis of silver nanoparticles and AgNO3 toxicity to Spirodela polyrhiza. Environ. Toxicol. Chem. 31, 1880-1886. doi: 10.1002/etc.1899

Kamal, M., Ghaly, A. E., Mahmoud, N., and Cote, R. (2004). Phytoaccumulation of heavy metals by aquatic plants. Environ. Int. 29, 1029-1039. doi: 10.1016/ S0160-4120(03)00091-6

Krantev, A., Yordanova, R., Janda, T., Szalai, G., and Popova, L. (2008). Treatment with salicylic acid decreases the effect of cadmium on photosynthesis in maize plants. J. Plant Physiol. 165, 920-931. doi: 10.1016/j.jplph.2006.11.014

Kremer, B. P., and Markham, J. W. (1982). Primary metabolic effect of cadmium in brown alga, Laminaria saccharina. Z. Pflanzenphysiol. 108, 125-130. doi: 10.1016/S0044-328X(82)80063-9

Li, Q., Chen, L.-S., Jiang, H.-X., Tang, N., Yang, L.-T., Lin, Z. H., et al. (2010). Effects of manganese-excess on $\mathrm{CO}_{2}$ assimilation, ribulose-1,5-bisphosphate carboxylase/oxygenase, carbohydrates and photosynthetic electron transport of leaves, and antioxidant systems of leaves and roots in Citrus grandis seedlings. BMC Plant Biol. 10:42. doi: 10.1186/1471-2229-10-42

Metwally, A., Finkemeier, I., Georgi, M., and Dietz, K.-J. (2003). Salicylic acid alleviates the cadmium toxicity in barley seedlings. Plant Physiol. 132, 272-281. doi: 10.1104/pp.102.018457

Meuwly, P., and Rauser, W. E. (1992). Alteration of thiol pools in roots and shoots of maize seedlings exposed to cadmium. Plant Physiol. 99, 8-15. doi: 10.1104/pp.99.1.8

Mishra, S., Srivastava, S., Tripathi, R. D., Kumar, R., Seth, C. S., and Gupta, D. K. (2006). Lead detoxification by coontail (Ceratophyllum demersum L.) involves induction of phytochelatins and antioxidant system in response to its accumulation. Chemosphere 65, 1027-1039. doi: 10.1016/j.chemosphere.2006. 03.033

Nriagu, J. O. (1996). A history of global metal pollution. Science 272, 223-224. doi: $10.1126 /$ science.272.5259.223

Oncel, I., Keles, Y., and Ustun, A. S. (2000). Interactive effects of temperature and heavy metal stress on the growth and some biochemical compounds in wheat seedlings. Environ. Pollut. 107, 315-320. doi: 10.1016/S0269-7491(99)00177-3

Oukarroum, A., Perreault, F., and Popovic, R. (2012). Interactive effects of temperature and copper on photosystem II photochemistry in Chlorella 
vulgaris. J. Photochem. Photobiol. B. 110, 9-14. doi: 10.1016/j.jphotobiol.2012. 02.003

Pardha-Saradhi, P., Yamal, G., Peddisetty, T., Sharmila, P., Nagar, S., Singh, J., et al. (2014a). Reducing strength prevailing at root surface of plants promotes reduction of $\mathrm{Ag}^{+}$and generation of $\mathrm{Ag}^{0} / \mathrm{Ag}_{2} \mathrm{O}$ nanoparticles exogenously in aqueous phase. PLoS ONE 9:e106715. doi: 10.1371/journal.pone. 0106715

Pardha-Saradhi, P., Yamal, G., Peddisetty, T., Sharmila, P., Singh, J., Nagarajan, R., et al. (2014b). Plants fabricate Fe-nanocomplexes at root surface to counter and phytostabilize excess ionic Fe. Biometals 27, 97-114. doi: 10.1007/s10534-0139690-7

Pardha-Saradhi, P., Yamal, G., Peddisetty, T., Sharmila, P., Singh, J., Nagarajan, R., et al. (2014c). Root system of live plants is a powerful resource for the green synthesis of Au-nanoparticles. RSC Adv. 4, 7361-7367. doi: 10.1039/c3ra $45370 \mathrm{~g}$

Parrotta, L., Guerriero, G., Sergeant, K., Cai, G., and Hausman, J.-F. (2015). Target or barrier? The cell wall of early- and later-diverging plants $v s$ cadmium toxicity: differences in the response mechanisms. Front. Plant Sci. 6:133. doi: 10.3389/ fpls.2015.00133

Posmyk, M. M., Kontek, R., and Janas, K. M. (2009). Antioxidant enzymes activity and phenolic compounds content in red cabbage seedlings exposed to copper stress. Ecotoxicol. Environ. Saf. 72, 596-602. doi: 10.1016/j.ecoenv.2008. 04.024

Prasad, K. V. S. K., Pardha-Saradhi, P., and Sharmila, P. (1999). Correlative changes in the activities of antioxidant enzymes under zinc toxicity in Brassica juncea. Environ. Exp. Bot. 42, 1-10. doi: 10.1016/S0098-8472(99)00013-1

Purcell, T. W., and Peters, J. J. (1998). Sources of silver n the environment. Environ. Toxicol. Chem. 17, 539-546. doi: 10.1002/etc.5620170404

Rai, P. K. (2009). Heavy metal phytoremediation from aquatic ecosystems with special reference to macrophytes. Crit. Rev. Environ. Sci. Technol. 39, 697-753. doi: 10.1080/10643380801910058

Rao, K. V. M., and Sresty, T. V. S. (2000). Antioxidative parameters in the seedlings of pigeonpea (Cajanus cajan (L.) Millspaugh) in response to $\mathrm{Zn}$ and Ni stresses. Plant Sci. 157, 113-128. doi: 10.1016/S0168-9452(00)00273-9

Ratte, H. T. (1999). Bioaccumulation and toxicity of silver compounds: a review. Environ. Toxicol. Chem. 18, 89-108. doi: 10.1002/etc.5620180112

Sakihama, Y., Cohen, M. F., Grace, S. C., and Yamasaki, H. (2002). Plant phenolic antioxidant and prooxidant activities: phenolics-induced oxidative damage mediated by metals in plants. Toxicology 177, 67-80. doi: 10.1016/S0300483X(02)00196-8

Schutzendubel, A., Nikolova, P., Rudolf, C., and Polle, A. (2002). Cadmium and $\mathrm{H}_{2} \mathrm{O}_{2}$-induced oxidative stress in Populus $x$ canescens roots. Plant Physiol. Biochem. 40, 577-584. doi: 10.1016/S0981-9428(02)01411-0

Shabnam, N., and Pardha-Saradhi, P. (2016). Floating and submerged leaves of Potamogeton nodosus exhibit distinct variation in antioxidant system as an ecophysiological adaptive strategy. Funct. Plant Biol. 43, 346-355. doi: 10.1071/ FP15293

Shabnam, N., Pardha-Saradhi, P., and Sharmila, P. (2014). Phenolics impart $\mathrm{Au}^{3+}$ stress tolerance to cowpea by generating nanoparticles. PLoS ONE 9:e85242. doi: 10.1371 /journal.pone.0085242

Shabnam, N., Sharmila, P., Kim, H., and Pardha-Saradhi, P. (2016). Light mediated generation of silver nanoparticles by spinach thylakoids/chloroplasts. PLoS ONE 11:e0167937. doi: 10.1371/journal.pone.0167937

Shabnam, N., Sharmila, P., and Pardha-Saradhi, P. (2017). Impact of ionic and nanoparticle speciation states of silver on light harnessing photosynthetic events in Spirodela polyrhiza. Int. J. Phytoremediat. 19, 80-86. doi: 10.1080/ 15226514.2016.1216083

Shabnam, N., Sharmila, P., Sharma, A., Strasser, R. J., Govindjee, and PardhaSaradhi, P. (2015). Mitochondrial electron transport protects floating leaves of long leaf pondweed (Potamogeton nodosus Poir) against photoinhibition: comparison with submerged leaves. Photosynth. Res. 125, 305-319. doi: 10.1007/s11120-014-0051-3

Shah, K., Kumar, R. G., Verma, S., and Dubey, R. S. (2001). Effect of cadmium on lipid peroxidation, superoxide anion generation and activities of antioxidant enzymes in growing rice seedlings. Plant Sci. 161, 1135-1144. doi: 10.1016/ S0168-9452(01)00517-9

Sharma, S. S., and Dietz, K.-J. (2009). The relationship between metal toxicity and cellular redox imbalance. Trends Plant Sci. 14, 43-50. doi: 10.1016/j.tplants. 2008.10.007

Stiborova, M. (1998). Cd ${ }^{2+}$ ions affect the quaternary structure of ribulose1,5-bisphosphate carboxylase from barley leaves. Biochem.Physiol. Pfl. 183, 371-378. doi: 10.1016/S0015-3796(88)80045-3

Stiborova, M., Ditrichova, M., and Benzinova, A. (1998). Mechanism of action of $\mathrm{Cu}^{2+}, \mathrm{Co}^{2+}$ and $\mathrm{Zn}^{2+}$ on ribulose- 1,5-bisphosphate carboxylase from barley (Hordeum vulgare L.). Photosynthetica 22, 161-167.

Stirbet, A., and Govindjee. (2012). Chlorophyll $a$ fluorescence induction: a personal perspective of the thermal phase, the J-I-P rise. Photosynth. Res. 113, 15-61. doi: $10.1007 /$ s11120-012-9754-5

Strasser, R. J., Srivastava, A., and Govindjee. (1995). Polyphasic Chl $a$ fluorescence transient in plants and cyanobacteria. Photochem. Photobiol. 61, 32-42. doi: 10.1111/j.1751-1097.1995.tb09240.x

Tripathi, B. N., Mehta, S. K., Amar, A., and Gaur, J. P. (2006). Oxidative stress in Scenedesmus sp. during short- and long-term exposure to $\mathrm{Cu}^{2+}$ and $\mathrm{Zn}^{2+}$. Chemosphere 62, 538-544. doi: 10.1016/j.chemosphere.2005.06.031

Tukendorf, A., and Rauser, W. E. (1990). Changes in glutathione and phytochelatins in roots of maize seedlings exposed to cadmium. Plant Sci. 70, 155-166. doi: 10.1016/0168-9452(90)90129-C

Van Assche, F., and Clijsters, H. (1986). Inhibition of photosynthesis in Phaseolus vulgaris by treatment with toxic concentration of zinc: effect on ribulose-1,5bisphosphate carboxylase/oxygenase. J. Plant Physiol. 25, 355-360. doi: 10.1016/ S0176-1617(86)80157-2

Wang, Y., Jiang, X., Li, K., Wu, M., Zhang, R., Zhang, L., et al. (2014). Photosynthetic responses of Oryza sativa L. seedlings to cadmium stress: physiological, biochemical and ultrastructural analyses. Biometals 27, 389-401. doi: 10.1007/s10534-014-9720-0

Xu, Q. S., Hu, J. Z., Xie, K. B., Yang, H. Y., Du, K. H., and Shi, G. X. (2010). Accumulation and acute toxicity of silver in Potamogeton crispus L. J. Hazar. Mater. 173, 186-193. doi: 10.1016/j.jhazmat.2009.08.067

Conflict of Interest Statement: The authors declare that the research was conducted in the absence of any commercial or financial relationships that could be construed as a potential conflict of interest.

Copyright (c) 2017 Shabnam, Sharmila, Govindjee, Kim and Pardha-Saradhi. This is an open-access article distributed under the terms of the Creative Commons Attribution License (CC BY). The use, distribution or reproduction in other forums is permitted, provided the original author(s) or licensor are credited and that the original publication in this journal is cited, in accordance with accepted academic practice. No use, distribution or reproduction is permitted which does not comply with these terms. 